\title{
EXOSOMES: NOVEL EFFECTORS OF HUMAN PLATELET LYSATE ACTIVITY
}

\author{
E. Torreggiani ${ }^{1, *}$, F. Perut ${ }^{1}$, L. Roncuzzi ${ }^{1}$, N. Zinii ${ }^{2,3}$, SR. Baglìo ${ }^{1}$ and N. Baldini ${ }^{1,4}$ \\ ${ }^{1}$ Laboratory for Orthopaedic Pathophysiology and Regenerative Medicine, Istituto Ortopedico Rizzoli, Bologna, Italy \\ ${ }^{2} \mathrm{CNR}$ - National Research Council, Institute of Molecular Genetics, Bologna, Italy \\ ${ }^{3}$ Laboratory of Muscoloskeletal Cell Biology, Istituto Ortopedico Rizzoli, Bologna, Italy \\ ${ }^{4}$ Department of Biomedical and Neuromotor Sciences, University of Bologna, Bologna, Italy
}

\begin{abstract}
Despite the popularity of platelet-rich plasma (PRP) and platelet lysate (PL) in orthopaedic practice, the mechanism of action and the effectiveness of these therapeutic tools are still controversial. So far, the activity of PRP and PL has been associated with different growth factors (GF) released during platelet degranulation. This study, for the first time, identifies exosomes, nanosized vesicles released in the extracellular compartment by a number of elements, including platelets, as one of the effectors of PL activity. Exosomes were isolated from human PL by differential ultracentrifugation, and analysed by electron microscopy and Western blotting. Bone marrow stromal cells (MSC) treated with three different exosome concentrations $(0.6 \mu \mathrm{g}$, $5 \mu \mathrm{g}$ and $50 \mu \mathrm{g}$ ) showed a significant, dose-dependent increase in cell proliferation and migration compared to the control. In addition, osteogenic differentiation assays demonstrated that exosome concentration differently affected the ability of MSC to deposit mineralised matrix. Finally, the analysis of exosome protein content revealed a higher amount of basic fibroblast growth factor (bFGF), vascular endothelial growth factor (VEGF), plateletderived growth factor (PDGF-BB) and transforming growth factor beta 1 (TGF- $\beta 1$ ) as compared to PL. In regards to RNA content, an enrichment of small RNAs in exosomes as compared to donor platelets has been found. These results suggest that exosomes consistently contribute to PL activity and could represent an advantageous nanodelivery system for cell-free regeneration therapies.
\end{abstract}

Keywords: Exosomes, platelet lysate, platelet richplasma, bone marrow stromal cells, growth factors, RNA, nanodelivery system, cell-free regeneration therapies.

\author{
*Address for correspondence: \\ Elena Torreggiani \\ Istituto Ortopedico Rizzoli \\ Laboratory for Orthopaedic Pathophysiology and \\ Regenerative Medicine \\ via di Barbiano 1/10 \\ 40136 Bologna, Italy
}

Telephone Number: +39516366563

FAX Number: +39516366897

E-mail: elena.torreggiani@ior.it

\section{Introduction}

Despite the remarkable ability of bone to undergo extensive remodelling and regeneration, prompt healing is sometimes impaired if the amount of bone loss is excessive or the local or systemic conditions are unfavourable. In order to increase the chances of cure in the context of regenerative medicine techniques as applied to orthopaedic conditions, new approaches based on platelet derivatives, such as platelet-rich plasma (PRP) and platelet lysate (PL), have attracted the attention of several investigators. PRP and PL contain a high concentration of growth factors (GF), cytokines and molecules that actively contribute to the tissue repairing process. In non-union fractures, characterised by a significant reduction of endogenous GF levels (Gandhi et al., 2005), platelet derivatives provide a carrier to deliver supra-physiologic concentrations of GF to the injury site, eventually improving tissue regeneration. This potential benefit has led to an extensive use of PRP and PL in the orthopaedic practice (Savarino et al., 2006; Dallari et al., 2007; Lane et al., 2013; Ruggiu et al., 2013; Zhu et al., 2013) as well as in different clinical applications such as musculoskeletal injury (Foster et al., 2009; Nguyen et al., 2011; Lee 2013), maxillofacial surgery (Fennis et al., 2002; Froum et al., 2002), dentistry (Soffer et al., 2003; Govindasamy et al., 2011; Chen et al., 2012; Malik et al., 2012), dermatology (Cho et al., 2012), soft tissue injuries (Carter et al., 2011; Liao et al., 2014), in addition to it being a medium supplement for in vitro cell culture systems (Warnke et al., 2013). However, despite the popularity of PRP treatments in bone healing, studies that analyse the effectiveness of such therapeutic tools are still controversial (Hall et al., 2013; Lee et al., 2013; van Bergen et al., 2013). $\mathrm{Up}$ to now, the regenerative potential of PRP and PL has been mainly attributed to their GF content that is released as a result of platelet degranulation. This differs depending on the preparation technique, which may influence platelet content and, consequently, GF availability (Perut $e t$ al., 2013; Passaretti et al., 2014).

PL activity might also be due to the efficient cell to cell transport system of GF and other bioactive molecules that is mediated by their encapsulation into nm-sized (30$100 \mathrm{~nm}$ ) vesicles, called exosomes. They derived from specialised intracellular compartments, known as late endosomes or multivesicular bodies (MVB), and released by cells under physiological and pathological conditions (Baglio et al., 2012; Kharaziha et al., 2012; Urbanelli et al., 2013). Exosome secretion has been described for most cells, both constitutively and upon activation signals (Raposo et al., 1996; Théry et al., 1999; de Jong et al., 2012). Recently, exosomes have also been successfully 
purified from many body fluids such as urine (Gonzales et al., 2010), blood (Caby et al., 2005; Grant et al., 2011), amniotic fluid (Keller et al., 2011) and pleural effusions (Bard et al., 2004). The presence of a wide range of functional proteins, mRNAs, microRNAs, and lipids within exosomes (Mathivanan et al., 2010; Record et al., 2011) has suggested their role as biological nanovectors mediating cell communication.

In this study, for the first time, we investigated the role of exosomes as effectors of PL activity in order to explore their therapeutic potential for cell-free therapies in bone regeneration. For this purpose, we isolated exosomes from different samples of human PL, and evaluated their content in terms of total RNA and growth factors expression. Finally, we demonstrated their effectiveness to influence MSC osteogenic differentiation and to promote cell proliferation and migration.

\section{Materials and Methods}

\section{Generation of human platelet lysate (PL)}

Platelet units were collected after their expiration date (5 days after harvesting). They were generated by a pool of 3-5 buffy coats and comprise an average of $3.07 \times 10^{11}$ platelets in $350 \mathrm{~mL}$ of plasma. According to the method Lohmann et al. (Lohmann et al., 2012), aliquots of $40 \mathrm{~mL}$ were frozen at $-80{ }^{\circ} \mathrm{C}$, thawed at $37{ }^{\circ} \mathrm{C}$, and centrifuged at 2,600 $\mathrm{x} \mathrm{g}$ for $30 \mathrm{~min}$ at room temperature (F34-6-38 rotor, Eppendorf $5810 \mathrm{R}$, Eppendorf, Milan, Italy). The supernatant (human platelet lysate, PL) was transferred into new tubes, and $2 \mathrm{U} / \mathrm{mL}$ heparin (Epsoclar, Mayne Pharma, Naples, Italy) was added before exosome isolation. A volume of $15 \mathrm{~mL}$ of the thawed solution was aliquoted and stored at $-80^{\circ} \mathrm{C}$. PL was centrifuged at $2,000 \times \mathrm{g}$ for $10 \mathrm{~min}$ at room temperature to remove membrane fragments and $2 \mathrm{U} / \mathrm{mL}$ heparin was added as an anticoagulant before addition to culture medium to avoid PL gel formation.

\section{Exosome isolation from PL}

Exosomes were isolated by serial low speed centrifugation followed by ultracentrifugation from 6 samples of PL. According to the method of Théry et al. (Théry et al., 2006), PL was centrifuged at $500 \times \mathrm{g}$ for $10 \mathrm{~min}$ (two times), 2,000 x $g$ for $15 \mathrm{~min}$ (two times) and 10,000 x $g$ for $30 \mathrm{~min}$ (two times) (F34-6-38 rotor, Eppendorf 5810 $\mathrm{R}$, Eppendorf) at $4{ }^{\circ} \mathrm{C}$ to remove cellular debris. The supernatant was then ultracentrifuged at $30,000 \mathrm{rpm}$ for $1 \mathrm{~h}$ at $4{ }^{\circ} \mathrm{C}$ (Ti 45 rotor, Beckman Coulter, Rome, Italy). The exosome pellet was washed once in a large volume of phosphate buffered saline (PBS) and centrifuged at $30,000 \mathrm{rpm}$ for $1 \mathrm{~h}$ at $4{ }^{\circ} \mathrm{C}$ ( Ti 70 rotor, Beckman Coulter, Milan, Italy). The exosome pellet was re-suspended in sterile PBS and stored at $-80^{\circ} \mathrm{C}$ until use. Exosome quantity was determined by the Bradford method (Bio-rad, Milan, Italy).

\section{Isolation of human platelets}

Approximately $12 \mathrm{~mL}$ of venous blood was drawn from healthy volunteers and collected in a collection tube supplemented with $2 \mathrm{U} / \mathrm{mL}$ heparin. Whole blood was centrifuged immediately at 1,000 rpm for $5 \mathrm{~min}$ at room temperature to obtain platelet-rich plasma (PRP). Then, PRP was transferred in a new tube and centrifuged at $1,900 \mathrm{rpm}$ for $15 \mathrm{~min}$. After removal of the supernatant, the resulting platelet pellet was used for Western blot and RNA analysis.

\section{Electron microscopy of PL-derived exosomes}

Exosomes derived from PL were resuspended in $2 \%$ paraformaldehyde (PFA) and loaded onto Formvarcarbon-coated grids. Next, exosomes were fixed in $1 \%$ glutaraldehyde, washed, and contrasted with a solution of uranyl oxalate, $\mathrm{pH} 7$, embedded in a mixture of $4 \%$ uranyl acetate and $2 \%$ methyl cellulose before observation with a Zeiss EM 109 electron microscope (Zeiss, Jena, Germany).

\section{Western blotting}

Purified exosomes or platelets were treated with RIPA lysis buffer ( $1 \%$ Triton X-100, $10 \%$ Na-deoxycholate, $5 \mathrm{M} \mathrm{NaCl}, 1 \mathrm{M}$ Tris-HCl, pH 7.4, 0.5 M EGTA, pH 8, $1 \mathrm{M} \mathrm{NaF}$ ) and protease inhibitors (Roche, Milan, Italy) for $20 \mathrm{~min}$ at $4{ }^{\circ} \mathrm{C}$. Nuclei and cell debris were removed by centrifugation. Samples solubilised in lysis buffer were quantified by the Bradford assay. Thirty $\mu \mathrm{g}$ of each sample was electrophoresed on a $10 \%$ SDS-PAGE and proteins were transferred to a nitrocellulose membrane (Thermo Fisher Scientific, Waltham, MA, USA). The membrane was blocked with $5 \%$ bovine serum albumin (BSA) (Sigma-Aldrich, Milan, Italy) in T-TBS $(0.1 \mathrm{M}$ Tris- $\mathrm{HCl} \mathrm{pH} 8,1.5 \mathrm{M} \mathrm{NaCl}$ and $1 \%$ Tween 20) for $1 \mathrm{~h}$ at room temperature, and subsequently incubated with anti-CD63 (1:1,000) (Santa Cruz Biotechnology, Santa Cruz, CA, USA) and anti-CD41 (1:1,000) (BioLegend, San Diego, CA, USA) antibodies overnight at $4{ }^{\circ} \mathrm{C}$. After vigorous washing in T-TBS, the membrane was incubated with the secondary antibody for $1 \mathrm{~h}$ at room temperature. Anti-rabbit antibody $(1: 1,000)$ for CD63 and anti-mouse antibody $(1: 1,000)$ for CD41, both conjugated to horseradish peroxidase (GE Healthcare, Milan, Italy) were diluted in T-TBS contained $5 \%$ BSA and used as secondary antibodies. Immunocomplexes were detected with the ECL Western blotting analysis system (Amersham Pharmacia, Piscataway, NJ, USA).

\section{Bone mesenchymal stem cell (MSC) culture}

After informed consent was obtained, bone marrow samples derived from the medullary cavity of the femur of 4 patients undergoing total hip replacement were flushed with PBS. Subsequently, mononuclear cells were isolated by the Ficoll Histopaque density gradient method (Sigma-Aldrich). Cells were maintained in $5 \% \mathrm{CO}_{2}$ humidified atmosphere at $37{ }^{\circ} \mathrm{C}$, in $\alpha$-minimum essential medium ( $\alpha \mathrm{MEM}$ ) supplemented with $100 \mathrm{U} / \mathrm{mL}$ penicillin, $0.1 \mathrm{mg} / \mathrm{mL}$ streptomycin plus $100 \mu \mathrm{mol} / \mathrm{L}$ ascorbic acid-2 phosphate (Sigma-Aldrich), and $10 \%$ foetal bovine serum (FBS) (Lonza, Milan, Italy). After 4 days of culture, cells adherent to culture plastic were considered as mesenchymal stem cells (MSC) and grown in $\alpha$ MEM supplemented with $100 \mathrm{U} / \mathrm{mL}$ penicillin, $0.1 \mathrm{mg} / \mathrm{mL}$ streptomycin, and $10 \%$ FBS (basal culture conditions). Passage 2-3 MSC were used in all experiments. To avoid contamination from FBS- 
derived exosomes, heat-inactivated FBS was centrifuged at $30,000 \mathrm{rpm}$ (rotor Ti 45, Beckman) overnight at $4{ }^{\circ} \mathrm{C}$. The pellet was discarded and the supernatant (exosome-free FBS, EFF) was passed through a $0.2 \mu \mathrm{m}$ filter and stored at $-20{ }^{\circ} \mathrm{C}$ until use for proliferation and differentiation assays.

\section{Labelling and uptake of PL-derived exosomes}

Exosome pellets were resuspended in PBS and stained with PKH26 Red Fluorescent Cell Linker Kit for General Cell Membrane Labelling (Sigma-Aldrich), according to the manufacturer's instructions with minor modifications. Briefly, exosomes $(2 \mu \mathrm{g})$ were diluted in PBS before $200 \mu \mathrm{L}$ of Diluent $C$ was added. As a control, $200 \mu \mathrm{L}$ of Diluent $\mathrm{C}$ with the same volume of PBS was used. $0.8 \mu \mathrm{L}$ of PKH26 dye was added to $200 \mu \mathrm{L}$ of Diluent $\mathrm{C}$ before being added to the exosomes and the control. Samples were mixed gently for $5 \mathrm{~min}$ before $400 \mu \mathrm{L}$ of $\alpha \mathrm{MEM}$ supplemented with $10 \%$ EFF was added to bind the excess dye. The samples were then centrifuged at 30,000 rpm (rotor Ti 45, Beckman) for $1 \mathrm{~h}$ at $4{ }^{\circ} \mathrm{C}$ and passed through a $0.2 \mu \mathrm{m}$ filter.

Two $\mu \mathrm{g}$ of the PKH26 labelled exosomes, or the same volume of the PKH26-PBS control, were resuspended in aMEM supplemented with $10 \% \mathrm{EFF}$ and added to $1 \times 10^{4}$ MSC maintained at $37{ }^{\circ} \mathrm{C}$ in a humidified atmosphere with $5 \% \mathrm{CO}_{2}$. After 4 and $20 \mathrm{~h}$ of incubation, uptake was stopped by washing and fixation in $3.7 \%$ paraformaldehyde (PFA) for $10 \mathrm{~min}$. Cells were then stained with a fluorescein isothiocyanate (FITC)-conjugated phalloidin (SigmaAldrich) and visualised with a Nikon Eclipse E800M fluorescence microscope (Nikon, Tokyo, Japan). All cells per high power-field were counted, and the percentage of PKH26 positively stained cells was determined. Five representative high power-fields per sample were evaluated.

\section{Proliferation assay}

Cell proliferation was assessed by the Alamar Blue test (Invitrogen, Monza, Italy). MSC were seeded in duplicate at a density of $1.5 \times 10^{4}$ cells per well ( 12 well plate) in aMEM with $10 \%$ EFF alone (control) or supplemented with two different exosome concentrations ( $5 \mu \mathrm{g}$ and $50 \mu \mathrm{g}$ ) or with the corresponding quantities of PL. $10 \%$ PL, containing an average amount of $0.6 \mu \mathrm{g}$ of exosomes plus several growth factors released from platelets, was used as a positive control. Cell proliferation was also evaluated by incubating MSC with the same amount of exosomes founded in $10 \%$ PL $(0.6 \mu \mathrm{g})$. At day 3 and 6 after seeding, cells were exposed to $10 \%$ Alamar Blue, and after $4 \mathrm{~h}$ the fluorescence was read at a wavelength of 535-590 nm using a microplate-reader (Tecan Infinite F200pro, Tecan, Milan, Italy). The results were expressed as mean of the relative fluorescence units (RFU) measured in two wells using four different MSC samples.

\section{Migration assay}

Cell migration was analysed by the Boyden chamber assay, using transwell inserts with 8 - $\mu$ m pore membrane filters (Costar, Sigma-Aldrich). MSC were grown to subconfluence $(70 \%)$ prior to harvesting by trypsinisation. Then, MSC were seeded in duplicate $\left(1.5 \times 10^{4}\right.$ cells per well in $200 \mu \mathrm{L}$ of serum-free $\alpha \mathrm{MEM}$ ) into the upper chamber of the Transwell system, and $600 \mu \mathrm{L}$ of serumfree $\alpha \mathrm{MEM}$ supplemented with two different exosome concentrations ( $5 \mu \mathrm{g}$ and $50 \mu \mathrm{g}$ ) or with the corresponding quantities of PL were applied to the lower chamber of the Transwell. $10 \%$ PL was used as a positive control. After $20 \mathrm{~h}$ of incubation at $37^{\circ} \mathrm{C}$, the upper sides of the filters were carefully washed with PBS and non-migrating cells were removed with a cotton swab. Migrated cells were fixed and stained on the lower side of the filter using $0.5 \%$ crystal violet dissolved in methanol for $30 \mathrm{~min}$. Chambers were rinsed with water, dried, and examined under a Nikon Eclipse-TE 2000-S microscope (Nikon). Migrated cells were quantified by counting.

\section{Osteogenic induction and mineralisation assay}

MSC were seeded in duplicate at a density of $1 \times 10^{4} /$ $\mathrm{cm}^{2}$ in basal culture conditions supplemented with $50 \mu \mathrm{g} / \mathrm{mL}$ L-ascorbic acid 2-phosphate and $10^{-8} \mathrm{M}$ dexamethasone (Sigma-Aldrich). At cell confluence, cells were incubated in $\alpha$ MEM supplemented with $10 \%$ EFF, $50 \mu \mathrm{g} / \mathrm{mL}$ ascorbic acid, $10^{-8} \mathrm{M}$ dexamethasone, and $10 \mathrm{mM} \beta$-glycerophosphate (Sigma-Aldrich), alone (control) or in presence of $5 \mu \mathrm{g}$ or $50 \mu \mathrm{g}$ of exosomes, or with the corresponding quantities of PL. The differentiation medium added to $10 \%$ PL was used as an additional control of osteogenic induction. Medium was changed twice-a-week. After 17 days, cells were fixed in $3.7 \%$ PFA (Sigma-Aldrich) for $20 \mathrm{~min}$, and calcium deposits were stained with $1 \%$ Alizarin Red S (pH 4.2) (Sigma-Aldrich) for $1 \mathrm{~h}$ at room temperature. The stained mineralised matrix was observed using a Nikon Eclipse-TE 2000-S microscope (Nikon).

For quantification of staining, $500 \mu \mathrm{L}$ of $10 \%$ cetylpyridinium chloride (CPC) (p/v) (Sigma-Aldrich) was added to each well, and the plate was incubated at room temperature for $30 \mathrm{~min}$ with shaking. The dye was then removed and $200 \mu \mathrm{L}$ aliquots were read in duplicate at $570 \mathrm{~nm}$ in 96-well format using a microplate-reader (Tecan Infinite F200pro, Tecan, Milan, Italy).

\section{Quantification of growth factors in PL and PL- derived exosomes by ELISA}

Exosome samples were lysed in RIPA lysis buffer, as previously described. PL samples were thawed and centrifuged to remove membrane fragments. The concentration of human basic fibroblast growth factor (bFGF), vascular endothelial growth factor (VEGF), platelet-derived growth factor (PDGF-BB) and transforming growth factor beta 1 (TGF- $\beta 1$ ) within PL and PL-derived exosomes was measured using commercially available reagents, based on a sandwich enzyme immunoassay technique (DuoSet ELISA; R\&D Systems, Minneapolis, MN, USA), and following the manufacturer's protocol. Standard reference curves were prepared using recombinant human bFGF, between 0 and $1,000 \mathrm{pg} / \mathrm{mL}$, and recombinant human VEGF, PDGF-BB and TGF- $\beta 1$, between 0 and 2,000 pg/mL. Briefly, $100 \mu \mathrm{L}$ of standards and samples were pipetted into a 96 -well microplate precoated with mouse anti-human bFGF, VEGF, PDGF-BB and TGF- $\beta 1$ antibodies. Biotinylated detection antibodies against human bFGF, VEGF, PDGF-BB and TGF- $\beta 1$ were 
used to detect growth factors bound by the immobilised antibodies. Following washing to remove any unbound antibody-enzyme reagents, a tetramethylbenzidine substrate solution was added to the wells. The reaction was stopped with $2 \mathrm{~N} \mathrm{H}_{2} \mathrm{SO}_{4}$, and the optical density was read using a microplate reader set to $450 \mathrm{~nm}$ (Tecan Infinite F200pro). The concentrations of bFGF, VEGF, PDGF-BB and TGF- $\beta 1$ were extrapolated by means of a dedicated software.

\section{RNA isolation and detection}

RNA was extracted from platelets and exosomes $(n=3)$ using NucleoSpin RNA II Kit (Macherey-Nagel, Düren, Germany) and Trizol ${ }^{\circledR}$ (Invitrogen), respectively, according to the manufacturer's protocols. The RNA quality, yield, and size of exosomal and cellular total RNA were evaluated with the RNA 6000 Nano Kit using the Agilent 2100 Bioanalyser (Agilent Technologies, Milan, Italy). Electropherograms were analysed using the Agilent 2100 Expert B.02.07 software that includes data collection, presentation, and interpretation functions.

\section{Statistical analysis}

Statistical analysis was performed by StatView5.01 software (SAS Institute Inc., Cary, NC, USA). Quantitative results were expressed as arithmetic mean plus or minus the standard deviation of the mean. The Wilcoxon signed rank test was used in a paired analysis to evaluate the effects of exosomes and PL on cell migration and mineralisation. The Mann-Whitney U-test was applied to assess the effects of exosomes and PL on cell proliferation and to detect differences in bFGF, VEGF, PDGF-BB and TGF- $\beta 1$ content in exosomes and PL as unpaired comparison for two independent variables. All $p$ values $<0.05$ were considered as statistically significant.

\section{Results}

\section{Identification of PL-derived exosomes}

Exosomes were isolated from six human platelet lysate samples through a series of low speed centrifugations followed by ultracentrifugations. In particular, an average of $2.9 \times 10^{3} \mu \mathrm{g} \pm 2.1 \times 10^{3}$ exosomes were isolated from platelet units, with an average volume of $350 \mathrm{~mL}$ and containing an amount of $3.07 \times 10^{11} \pm 0.83 \times 10^{11}$ platelets. As extensively described in literature (Lehmann et al., 2008; Lasser et al., 2011; Sokolova et al., 2011; Baglio et al., 2012; Mineo et al., 2012; Salomon et al., 2013; Tomasoni et al., 2013), the presence of exosomes was determined by electron microscopy. Exosomes with a characteristic rounded, cup-shaped morphology, and a typical size range of 30-100 $\mathrm{nm}$ are shown in Fig. 1a. Exosome purity was validated by Western blot for the expression of CD63, a specific exosomal marker (Théry et al., 2002; Mathivanan et al., 2010), and CD41, a heterodimeric integral membrane protein expressed in platelets and megakaryocytes (Heijnen et al., 1999; Italiano et al., 2010) (Fig. 1b). The results revealed that PL-derived exosomes were positive for the tetraspanins CD63, while no amount of CD41 was detected, suggesting that the exosome preparations obtained were pure and devoid of micro-vesicle contamination (Heijnen et al., 1999).

\section{Exosome uptake by MSC}

To examine whether exosomes from human platelet lysate can be taken up by MSC, PKH26 labelled exosomes (red) were incubated with MSC at two different time points and examined using fluorescence microscopy. After $4 \mathrm{~h}$ of incubation, a few exosomes were taken up by MSC with a localisation mainly in the cytoplasm (data not shown). After $20 \mathrm{~h}$, exosomes were taken up by $98 \% \pm 1.8 \%$ of MSC and accumulated especially in the perinuclear region (Fig. 2). As expected, no fluorescent signal was detected in the control.

\section{Effect of exosomes on MSC functions}

Since MSC were shown to internalise PL-derived exosomes, we aimed to determine whether exosomes are able to influence MSC activities, such as proliferation, migration, and osteogenic differentiation.

First, MSC proliferation was measured in the presence of three different concentrations of exosomes $(0.6 \mu \mathrm{g}, 5 \mu \mathrm{g}$ and $50 \mu \mathrm{g}$ ) or with $5 \mu \mathrm{g}$ and $50 \mu \mathrm{g}$ of PL at day 3 and 6 after seeding. As expected, the proliferation of MSC in every culture condition increased from the seeding to the end-point with a log phase. In particular, exosomes were capable to induce a significant increase in the MSC proliferation rate compared to control medium $(\alpha \mathrm{MEM}$ with $10 \%$ EFF) (Fig. 3). At day 6, the amount of $0.6 \mu \mathrm{g}$

\section{a}

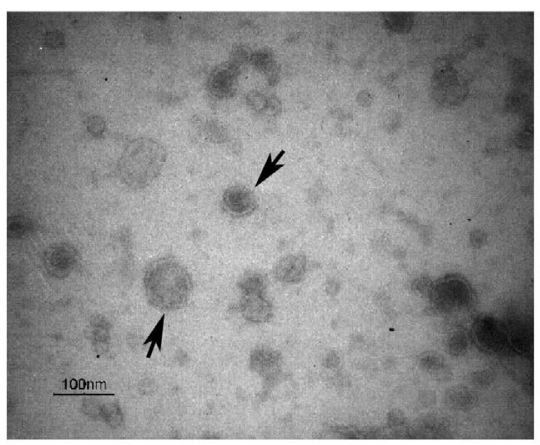

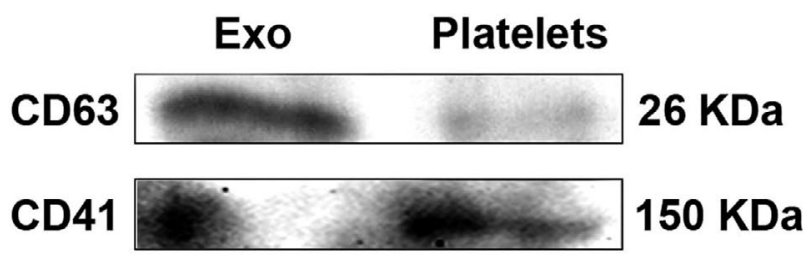

Fig. 1. Characterisation of PL-derived exosomes. Exosomes isolated from platelet lysate were examined by electron microscopy. Scale bar $=100 \mathrm{~nm}$ (a). Exosome purity was assessed also by Western blotting for the expression of the specific exosomal marker CD63 and for the expression of CD41, a glycoprotein expressed in platelets (b). 
PKH26

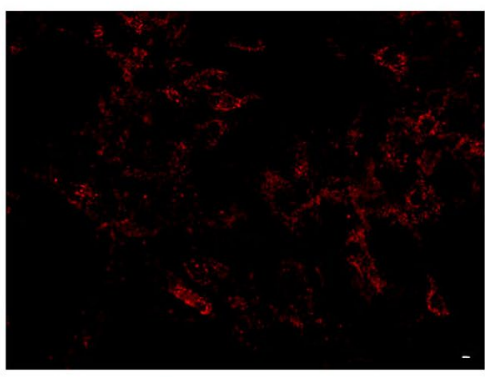

Exo

PBS

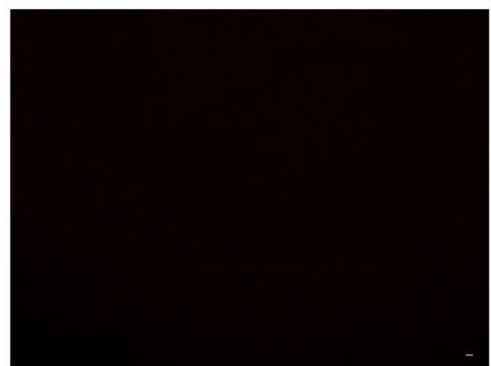

actin
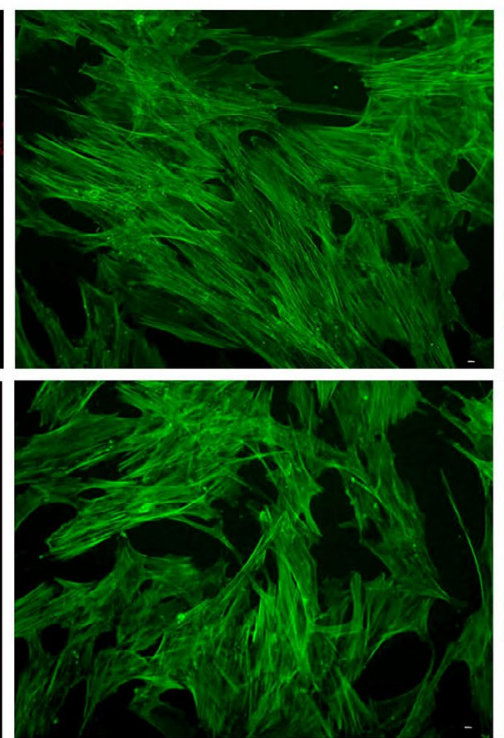

merge
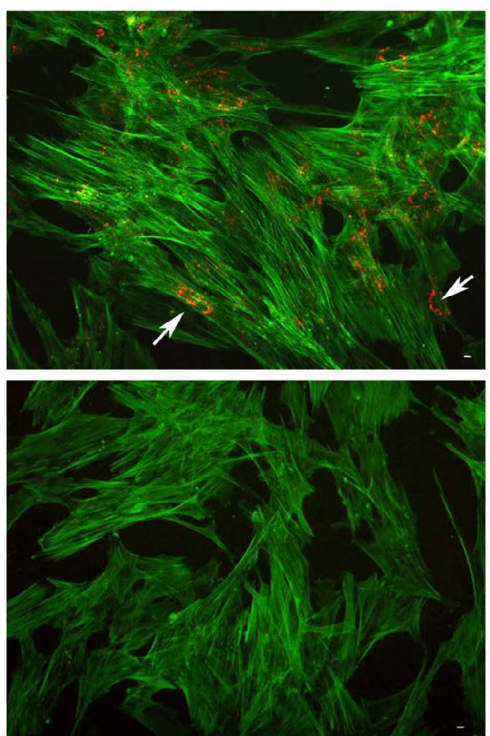

Fig. 2. Uptake of PL-derived exosomes by MSC. $2 \mu \mathrm{g}$ of the PKH26-labelled PL exosomes (red) (upper panel) or a PKH26-PBS control (lower panel) were added to 1 x $10^{4} \mathrm{MSC}$ and incubated at $37{ }^{\circ} \mathrm{C}$ for $20 \mathrm{~h}$. The cell uptake of the fluorescently labelled PL-derived exosomes was detected by fluorescence microscopy. Cells were fixed and actin filaments were stained with a FITC-conjugated phalloidin (green). Arrows indicate exosome localisation. Scale bar $=10 \mu \mathrm{m}$.

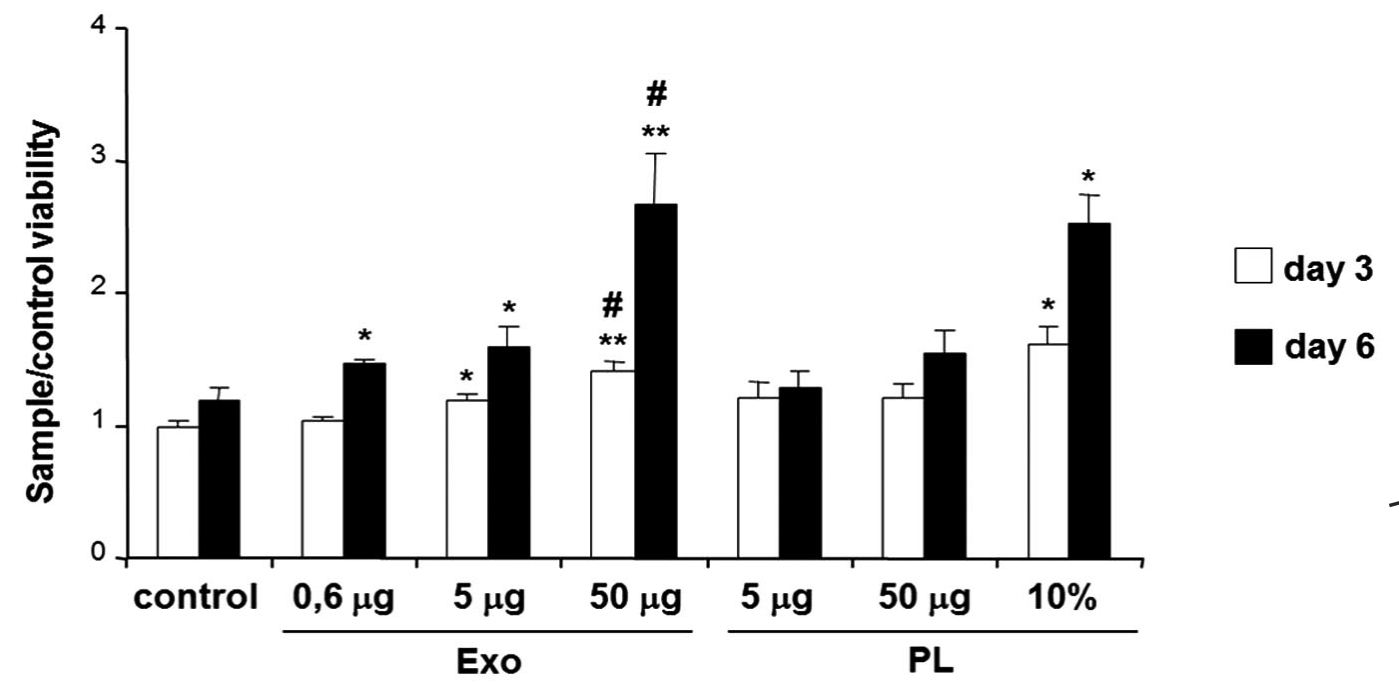

Fig. 3. Effect of exosomes on MSC proliferation. MSC were exposed to $\alpha \mathrm{MEM}$ with $10 \%$ EFF alone (control), or supplemented with $0.6 \mu \mathrm{g}, 5 \mu \mathrm{g}$ and $50 \mu \mathrm{g}$ of PL-derived exosomes or PL. $10 \%$ PL served as a positive control. Cell proliferation was assessed at different time points by Alamar blue assay and quantified by a fluorescence microplate reader. The results were expressed as mean of viability rate in respect to cells in control medium (EFF) at day 3. Data derived from six independent experiments. Significant difference between control vs. $0.6 \mu \mathrm{g}$ of exosomes at day $6,5 \mu \mathrm{g}$ of exosomes and $10 \%$ PL both at day 3 and day $6\left(^{*}\right)(p<0.05)$; highly significant difference between control vs. $50 \mu \mathrm{g}$ of exosomes both at day 3 and day $6(* *)(p<0.05)$; significant change between $5 \mu \mathrm{g} v s .50 \mu \mathrm{g}$ of exosomes both at day 3 and day $6(\#)(p<0.05)$.

of exosomes was sufficient to induce a significant 1.2-fold increase in MSC proliferation (1.47 \pm 0.038$)$, as compared to control condition $(1.19 \pm 0.104)$. Since day 3 , a similar trend was also observed when cells were treated with both $5 \mu \mathrm{g}$ and $50 \mu \mathrm{g}$ of exosomes. In addition, the proliferation rate induced by $50 \mu \mathrm{g}$ of exosomes was much more relevant to that observed with $0.6 \mu \mathrm{g}$ and $5 \mu \mathrm{g}$ exosome concentration during the whole cell culture, demonstrating a dose-dependent increase in cell growth. The culture of
MSC with $50 \mu \mathrm{g}$ of exosomes also showed a proliferation rate similar to that obtained with $10 \% \mathrm{PL}$, containing an average amount of $0.6 \mu \mathrm{g}$ of exosomes plus several free growth factors present in PL preparations, and used as a positive control.

Next, to investigate the potential chemotactic effect of PL-derived exosomes and their influence on MSC migration, we performed a migration assay (Fig. 4). After an incubation time of $20 \mathrm{~h}$, a total number of $7.87 \pm 0.72$ 
a
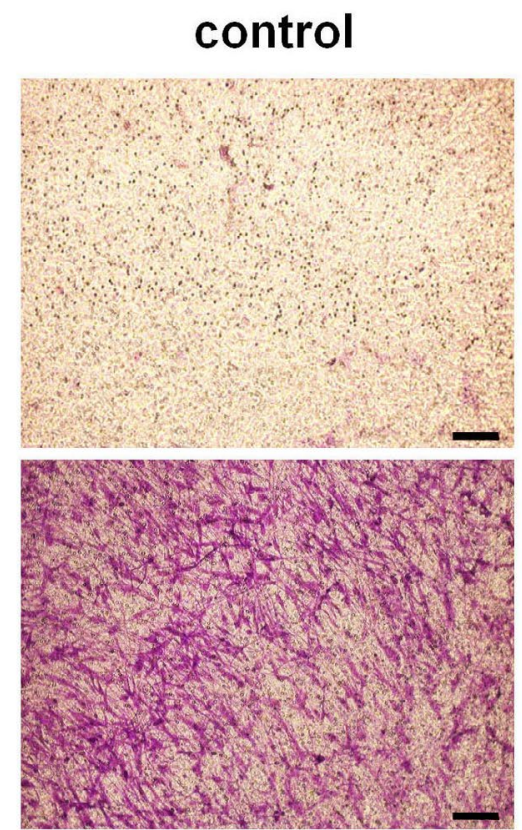

$10 \% \mathrm{PL}$
$5 \mu \mathrm{g}$ Exo
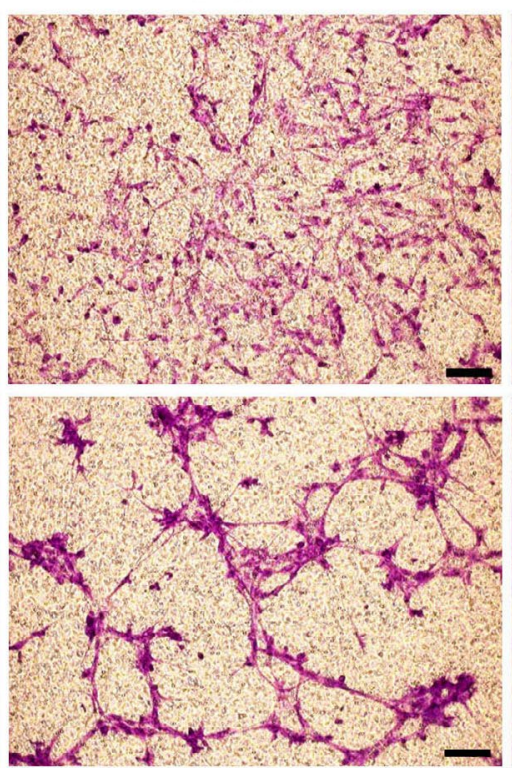

$5 \mu \mathrm{g} \mathrm{PL}$
$50 \mu \mathrm{g}$ Exo

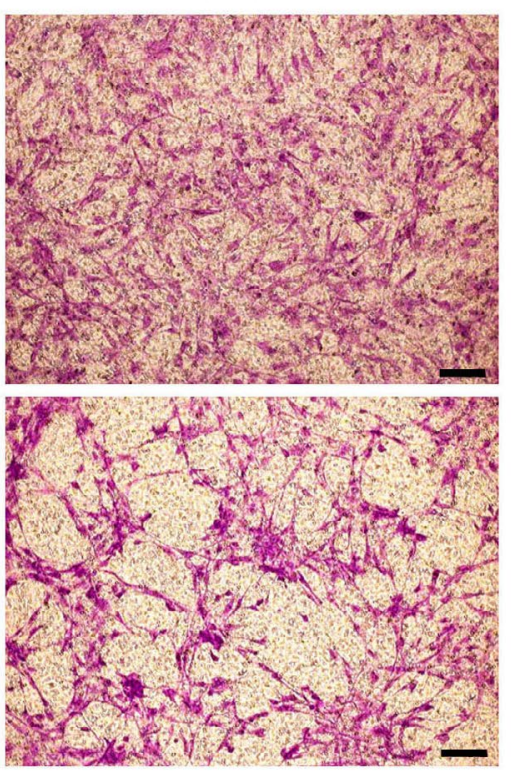

$50 \mu \mathrm{g} \mathrm{PL}$

b

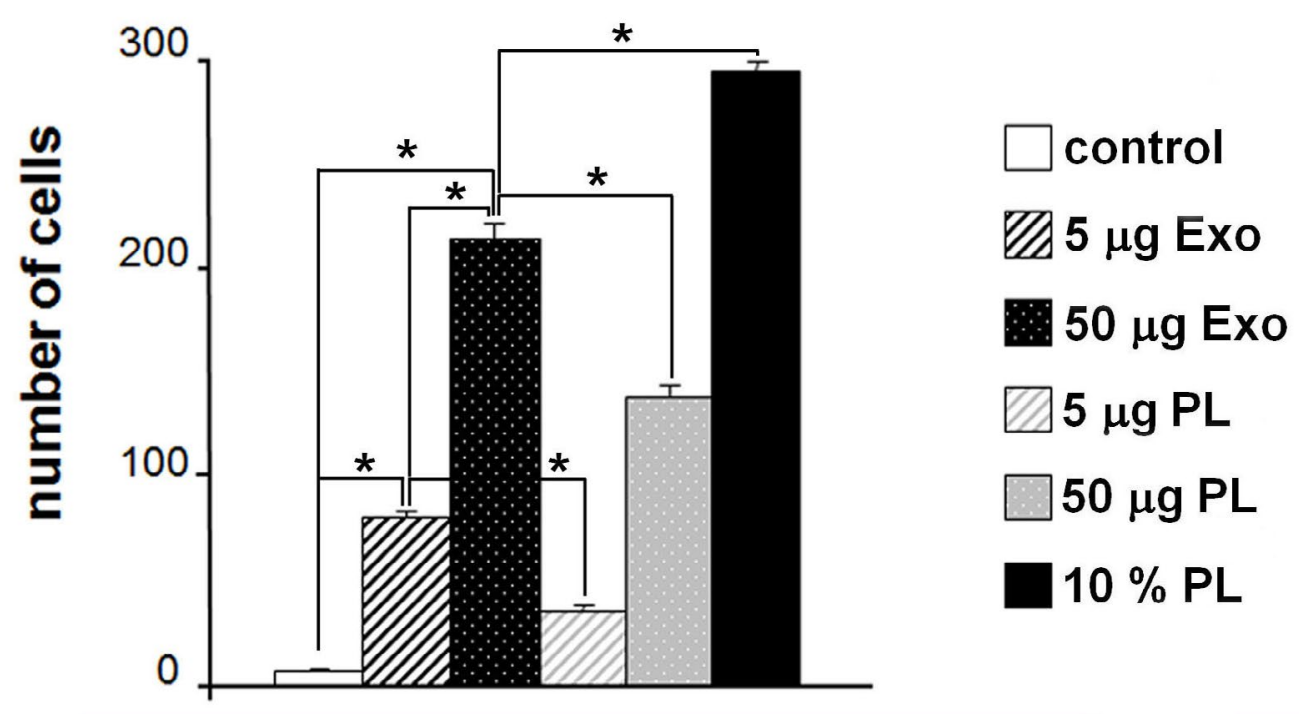

Fig. 4. Effect of exosomes on MSC migration. MSC migration as analysed by Boyden chamber assay. Representative images of MSC localised on the lower site of the Boyden filter after migration through the membrane in response to $5 \mu \mathrm{g}$ and $50 \mu \mathrm{g}$ of PL-derived exosomes or the same concentrations of PL or to serum free which served as a negative control. $10 \%$ PL was used as a positive control of cell migration. Scale bar $=50 \mu \mathrm{m}$. (a). Data represent the number of cells migrated in response to different culture conditions. Values are the mean \pm standard deviation of the number of cells per high-power field that migrated through the membrane pores relative to the negative control. Results derived from three independent experiments performed in triplicate $(* p<0.05)$ (b). Significant difference between control vs. $5 \mu \mathrm{g}$ and $50 \mu \mathrm{g}$ of PL and $10 \% \mathrm{PL}(p<0.05)$; Significant change between $5 \mu \mathrm{g} v s$. $50 \mu \mathrm{g}$ of PL $(p<0.05)$; Significant difference between $50 \mu \mathrm{g}$ of exosomes or PL $v s .10 \%$ PL $(p<0.05)$.

cells migrated through the membrane without the addition of any stimulus (negative control). Both exosomes and PL conditions induced a significant increase in migration. In particular, a 10.3- and a 27.1-fold increased migration were detected by using $5 \mu \mathrm{g}$ or $50 \mu \mathrm{g}$ of exosomes, respectively, demonstrating a dose-dependent effect, as previously observed for MSC proliferation. Moreover, cell mobilisation induced by exosomes was significantly higher than that promoted by PL at the same concentrations (Fig. 4b).
We subsequently assessed if the osteogenic differentiation potential of MSC was influenced by PLderived exosomes. Cells were cultured with specific osteogenic factors with or without exosomes or PL for 17 days, and osteogenic differentiation was evaluated by staining of calcium phosphate precipitates with Alizarin S Red. As shown in Fig. 5a, PL induced a MSC differentiation comparable to that observed in the control, without any substantial difference for the concentration used. The two concentrations of exosomes differently 
a

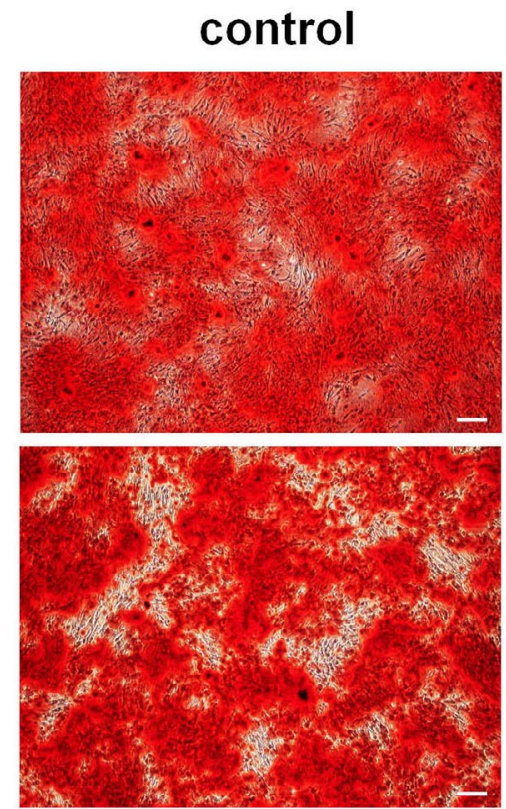

$10 \% \mathrm{PL}$
$5 \mu \mathrm{g}$ Exo
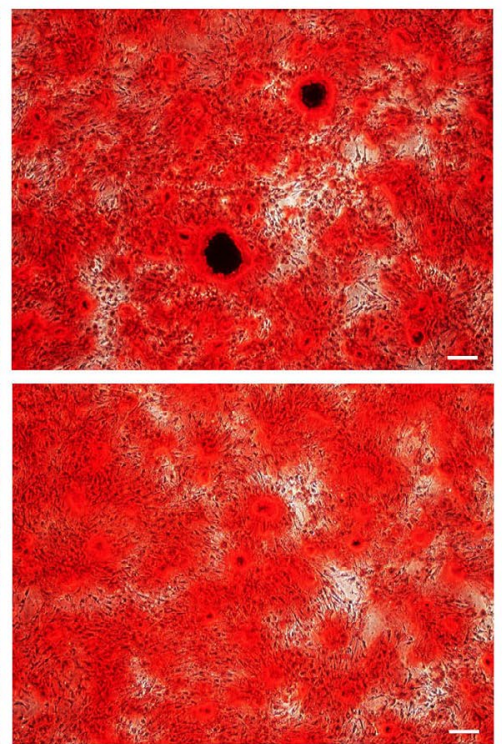

$5 \mu \mathrm{g} \mathrm{PL}$
$50 \mu \mathrm{g}$ Exo
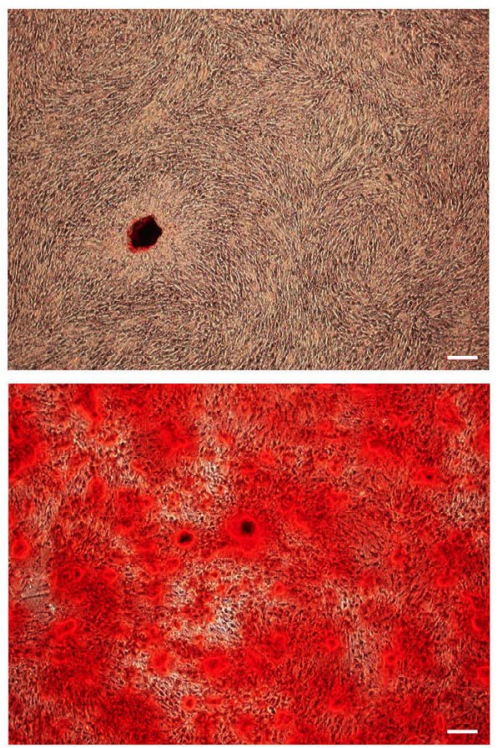

$50 \mu \mathrm{g}$ PL

b

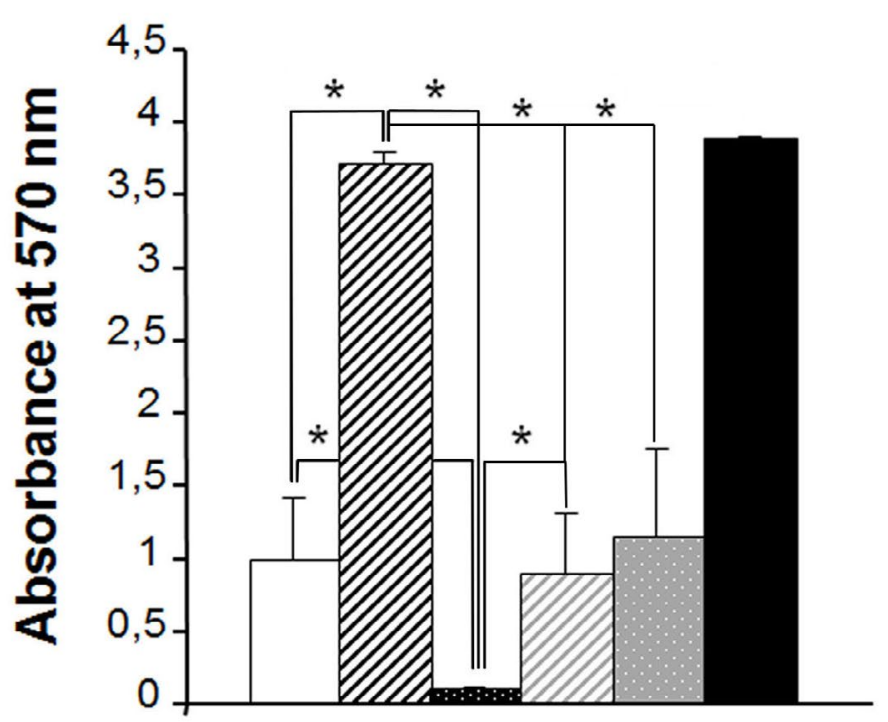

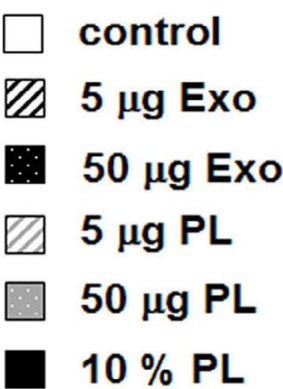

$10 \% \mathrm{PL}$

Fig. 5. Osteogenic differentiation capacity of MSC in relation to PL and PL-derived exosomes. MSC were cultured in $\alpha \mathrm{MEM}$ with $10 \% \mathrm{EFF}$ and specific osteogenic factors alone (control) or in the presence of $5 \mu \mathrm{g}$ and $50 \mu \mathrm{g}$ of exosomes or PL. The differentiation medium added to $10 \%$ PL was used as an additional control of osteogenic induction. Osteogenic differentiation was analysed after 17 days by staining of calcium phosphate precipitates with Alizarin Red S. Scale bar $=200 \mu \mathrm{m}$ (a). Quantification of Alizarin Red staining by extraction with $10 \%$ CPC. The results were expressed as mean of the absorbance values \pm standard deviation derived from three independent experiments $(* p<0.05)(\mathbf{b})$.

affected osteogenic differentiation. MSC cultured with $5 \mu \mathrm{g}$ of exosomes resulted in a substantial osteogenesis, characterised by the presence of several mineralised nodules larger than those found in control and PL cultures, whereas the higher exosome concentration significantly decreased the ability of MSC to deposit mineralised matrix. These results were confirmed quantifying the amount of calciumcontaining mineral deposition by CPC assay (Fig. 5b).
PL-derived exosomes express bFGF, VEGF, PDF-BB and TGF- $\beta 1$

In order to investigate whether potential factors are involved in the observed modulation of MSC functions, bFGF, VEGF, PDF-BB and TGF- $\beta 1$ were evaluated in PL and PL-derived exosomes. ELISA assays revealed an enrichment of all these growth factors in exosomes compared to PL. In particular, the expression of bFGF, 

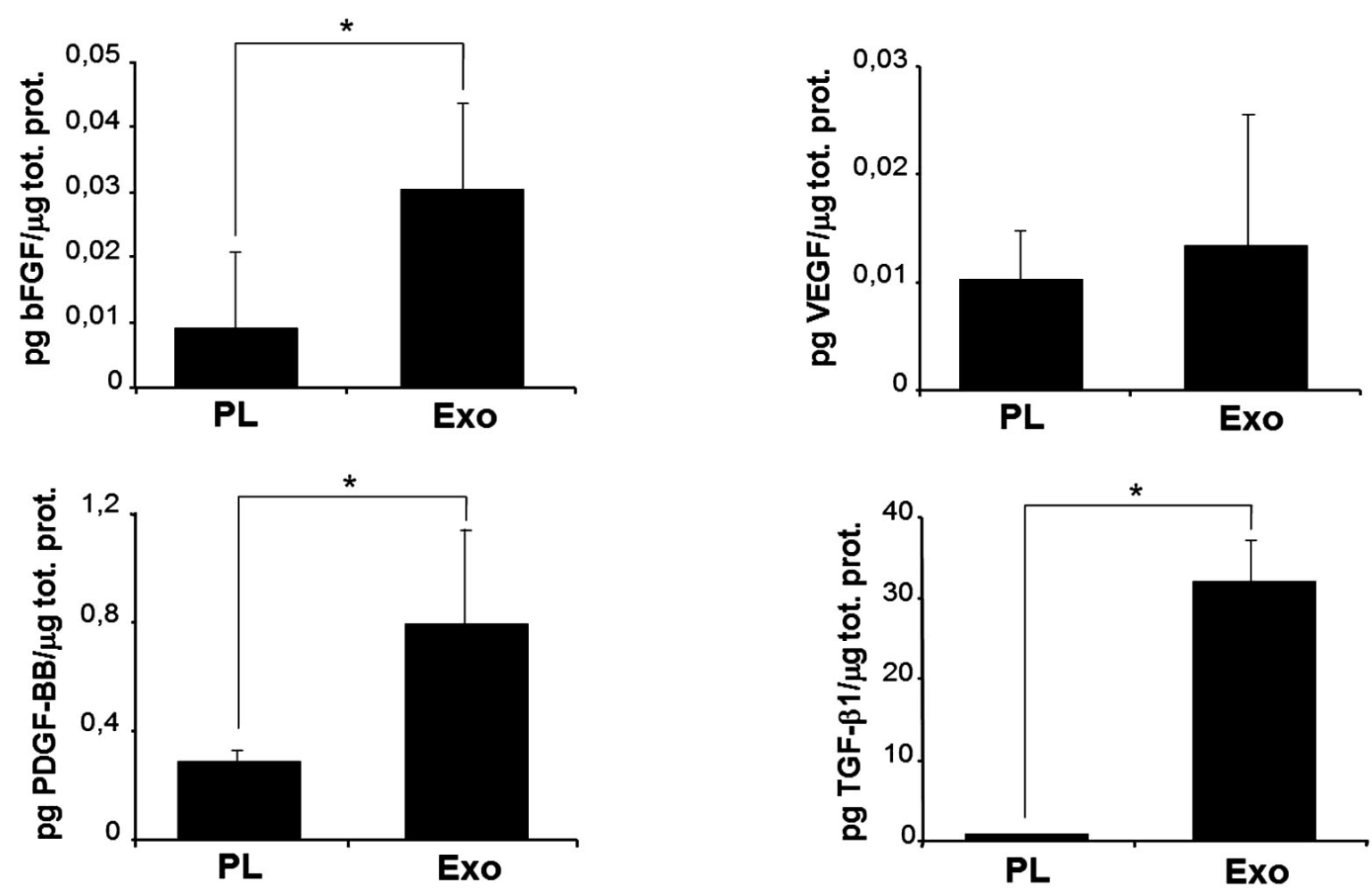

Fig. 6. Evaluation of growth factors in PL and PL-derived exosomes. To determine bFGF, VEGF, PDGF-BB and TGF- $\beta 1$ concentration, $100 \mu \mathrm{L}$ of PL or PL-derived exosomes were subjected to ELISA analysis. Data were normalised for the total protein content and showed the presence of bFGF, VEGF, PDGF-BB and TGF- $\beta 1$ in PLderived exosomes at a higher amount compared to PL $(* p<0.05)$. Results represent the mean \pm standard deviation obtained from $n=3$ exosome samples and $n=3$ PL analysed in triplicate.

\section{Platelet RNA}

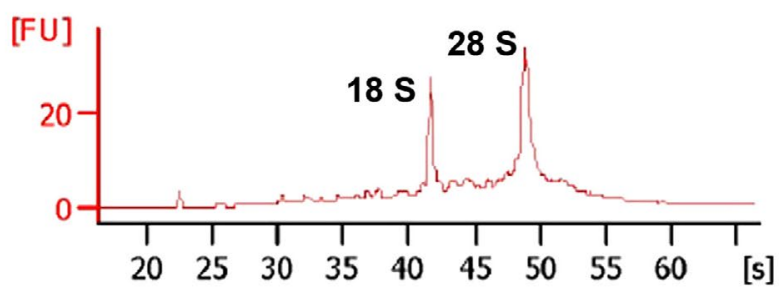

Exosomal RNA

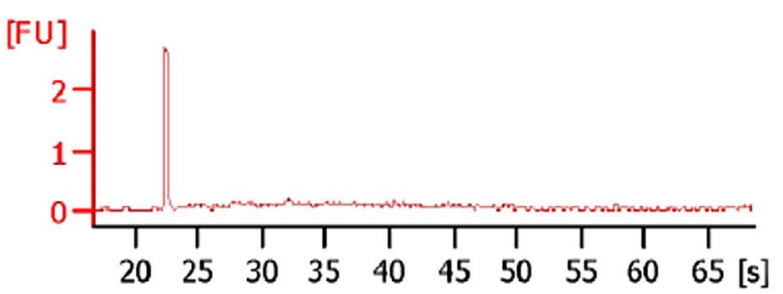

Fig. 7. Bioanalyser analysis of cellular and exosomal total RNA. Cellular and exosomal RNA was analysed with the RNA Nano 6000 Kit using an Agilent 2100 Bioanalyzer. The electropherograms show the peak distribution in seconds migration time (s) and fluorescence intensity (FU) of total RNA in platelets and in exosomes. The electropherograms are representative of $n=3$.

PDGF-BB and TGF- $\beta 1$ in the nanovescicles was significantly higher compared to PL (3.3-fold increased expression for bFGF; 2.7-fold for PDGF-BB and 35.5-fold for TGF- $\beta 1$ ) (Fig. 6).

\section{PL-derived exosomes contain RNA}

To assess the RNA profiling of both exosomes and cells, total RNA was analysed with the RNA 6000 Nano Kit using an Agilent 2100 Bioanalyzer. As shown in Fig. 7, the bioanalyser electropherogram of exosomes was different with regard to the pattern of cellular RNA. In platelets the most dominant peaks were $18 \mathrm{~S}$ and $28 \mathrm{~S}$ rRNA. Otherwise, exosomal RNA differed in their profile as exosomes lacked the two rRNA peaks and were rich in short RNA, as represented by the peak between 20 and $25 \mathrm{~s}$.

\section{Discussion}

The need to achieve prompt and adequate bone regeneration in cranial, oral, maxillofacial, and orthopaedic surgery is a key issue in regenerative medicine, resulting in the development of several techniques (Fleming et al., 2000). Among these, platelet derivatives such as PRP and PL 
have been employed as special sources of GF mimicking the physiological mechanisms of bone healing. Several studies have shown their beneficial potential for a variety of indications (Hee et al., 2003; Sanchez et al., 2003; Franchini et al., 2005). However, despite the hype, an active debate on the clinical benefits of these solutions is still ongoing. Indeed, even if PRP and PL are being suggested as cost-effective adjuvants with low morbidity and low associated complications, a clear connection between their use, the underlying molecular mechanisms, and a positive clinical outcome is still lacking. Up to now, the effect of platelet concentrates on bone cells has been attributed to their GF released during platelet degranulation. However, PL activity might also be due to the efficient intercellular communication of bioactive molecules, mediated by nanosized vesicles, identified as exosomes.

Based on these considerations, the aim of this study was to investigate if exosomes can be considered as relevant effectors of PL activity.

We isolated exosomes from human PL (PL) by ultracentrifugation and evaluated their potential effect on MSC functionality as compared to PL. Since PLderived exosomes were shown to interact with MSC, we further examined whether exosomes would affect cell proliferation, migration, and osteogenic differentiation. Based on literature data (Bu et al., 2006; Yang et al., 2011), we treated cells with different exosome concentrations. $10 \% \mathrm{PL}$, containing an average amount of $0.6 \mu \mathrm{g}$ of exosomes plus growth factors released from platelets, was included as a positive control to confirm the cell-system model, since it represents the percentage of PL mostly used as effective supplement for MSC cultivation in vitro (Schallmoser et al., 2007; Schallmoser et al., 2008; Bieback et al., 2009) and it has been demonstrated to induce MSC proliferation and osteogenic differentiation (Fekete et al., 2012; Lohmann et al., 2012; JonsdottirBuch et al., 2013). MSC cultured with exosomes showed a significant, dose-dependent increase in cell proliferation and migration as compared to the EFF control, suggesting a potential enrichment of proteins or other bioactive molecules related to these processes, within exosomes. In particular, the amount of $0.6 \mu \mathrm{g}$ of exosomes contained in $10 \% \mathrm{PL}$, is sufficient to induce a significant increase of MSC growth. However, the proliferation rate observed with this concentration is significantly lower than that obtained with $10 \%$ PL, since the effect of PL is also mediated by free growth factors released from platelets. This hypothesis is supported by Hemeda et al. (Hemeda et al., 2014) who recently reported the importance of several factors (i.e., growth factors, metabolites, etc.) to be considered in PL activity.

Interestingly, the proliferation rate of MSC cultured in $50 \mu \mathrm{g}$ of exosomes both at day 3 and day 6 , was comparable to that induced by $10 \% \mathrm{PL}$, suggesting that, at this concentration, exosomes possess the same potential to stimulate MSC growth as that provided by $10 \% \mathrm{PL}$. Similar exosome effects have also been observed in tumour (O'Brien et al., 2013; Roccaro et al., 2013) and normal cell-system models (Zhang et al., 2012b; Salomon et al., 2013), indicating that a cocktail of factors contained in exosomes can boost cell proliferation and migration. PLderived exosomes showed to affect also the osteogenic differentiation potential of MSC. In particular, we observed that osteogenically stimulated confluent cells did not lose their lineage differentiation ability in the presence of $5 \mu \mathrm{g}$ of exosomes or PL. Indeed, MSC treated with the lower dose of exosomes showed a comparable pattern of osteogenesis as that obtained by culturing cells with $10 \%$ $\mathrm{PL}$, suggesting that exosomes have the same potential to steer MSC toward the osteogenic differentiation as that provided by $10 \%$ PL. On the other hand, the ability of MSC to deposit mineralised matrix was significantly decreased after exposure to $50 \mu \mathrm{g}$ of exosomes. The lower effect of $50 \mu \mathrm{g}$ of exosomes, compared with the other culture conditions, might be attributed to the higher proliferation rate observed in the presence of this exosome concentration.

In this study, we demonstrated that a substantial part of proliferation, migration and osteogenic effects of the $\mathrm{PL}$ is mediated by exosomes. However, the exact nature of the signals involved in these processes and delivered by PL-derived exosomes, as well as the mechanism of action, is still unknown. The involvement of several soluble mediators in the activity of PL, such as coagulation, vasoactive, and growth factors is well documented (Slater et al., 1995; Rendu and Brohard-Bohn., 2001). Among these factors, PDGFs, IGFs, VEGF, TGF- $\beta$, and bFGF have the closest association with bone healing, as they are involved in bone regeneration and are potential regulators of osteoblastic migration, proliferation, and differentiation (Lieberman et al., 1998; Lind, 1998; Schmidt et al., 1998; Gerber et al., 1999; Schliephake, 2002).

Recent studies have described the expression of growth factors, or other usually soluble mediators, in association with the exosome membrane (Zhang et al., 2006; Sanderson et al., 2008; Seelenmeyer et al., 2008). Based on this evidence, we evaluated if bFGF, VEGF, PDGF-BB and TGF- $\beta 1$ of PL were also associated with exosomes. We chose to test these growth factors, because they have been extensively described as actively involved in osteogenesis and angiogenesis (Montero et al., 2000; Kilian et al., 2004; Presta et al., 2006; Graham et al., 2009; Kempen et al., 2010; Caplan and Correa., 2011; Malhotra et al., 2013). Moreover, recombinant bFGF, PDGF-BB and VEGF have been shown to favour fracture healing (Eckardt et al., 2005; Moore et al., 2009; Kawaguchi et al., 2010). Our results showed a significant enrichment of bFGF, PDGF-BB and TGF- $\beta 1$ expression in exosomes compared to $\mathrm{PL}$, suggesting a possible physiological role for PL-derived exosomes as a means of delivering these growth factors or other mediators though the extracellular space.

Up to now, GF present in biologic fluids have been accounted as free molecules. Our discovery, as well as similar observations reported by others (Clayton et al., 2007; Clayton et al., 2008; Wang et al., 2008), showed that GF can exist also encapsulated into exosomes. This evidence should be deeply considered every time that a specific factor is evaluated, in order to avoid potential false positives. For instance, we previously demonstrated that a high serum level of FGF-2 in children with orthopaedic 
diseases was correlated with a good bone healing, suggesting that FGF-2 may be a sentinel factor that may predict the outcome of a severe bone lesion. However, our test showed a consistent number of false positives, where FGF-2 levels lower than the threshold value were also detected in some subjects with a good clinical outcome (Granchi et al., 2013). This result, apparently inconsistent, may be explained evaluating the expression of FGF-2 inside serum-derived exosomes which, as demonstrated in the present study, may be enriched of this osteoinductive factor, thus leading to bone healing. The analysis of GF or other bioactive molecules both free and encapsulated may help in the development of more reliable predictive assays to be used in regenerative approaches.

Another possible mechanism involved in mediating exosome effects could be via the exosomal delivery of RNA. Several reports have revealed the presence of mRNA and microRNA in exosomes derived from different cell sources (Camacho et al., 2013; Lv et al., 2013; Moldovan et al., 2013). In this study, we demonstrated that also PLderived exosomes contain short RNAs, suggesting that these vesicles can be considered as biological nanovectors, which may transfer specific signals from platelets to other cells involved in bone healing. Recently, Plè et al. have demonstrated the presence of more than 492 different mature microRNA in human platelets (Plé et al., 2012), some of which, are implicated in proliferation (Zhang et al., 2012a), migration (Zhao et al., 2014), and osteogenic differentiation (Trompeter et al., 2013). Therefore, it would be fundamental to investigate if these micro-RNAs are expressed in PL-derived exosomes as well as to evaluate the presence of other RNA selectively expressed in exosomes, which might mediate specific effects. Previous studies, indeed, have shown that exosomes from mast cells contain RNA and that the RNA profile differs between exosomes and their donor cells (Valadi et al., 2007).

A full characterisation of PL-derived exosome content, both at the RNA and protein levels, may provide detailed information on the molecular mechanisms whereby platelet derivatives interact with cells during bone regeneration, and may help to explain the discrepancies seen in the translation from preclinical studies to clinical use of platelet derivatives. One of the most plausible hypotheses is that platelets induce tissue repair and angiogenesis through a paracrine effect mediated by exosomes (Brill et al., 2004; Rhee et al., 2004; Brill et al., 2005). An increasing number of studies, indeed, demonstrated that these nanovescicles play an important role in intercellular communication and represent one of the primary mediators of paracrine effect of their donor cells (Lai et al., 2004). Sahoo et al. showed that exosomes from human CD34+ stem cells mediate their proangiogenic paracrine activity both in vitro and in vivo (Sahoo et al., 2011). Similarly, Lai et al. demonstrated that bone marrow-derived MSC mediated its cardioprotective paracrine effect by secreting exosomes, thus reducing myocardial ischemia/reperfusion injury (Lai et al., 2010).

The active paracrine trophic potential of exosomes introduces a radically different dimension to the therapeutic applications of MSC in regenerative medicine. Indeed, by replacing transplantation of MSC with a cell-free approach based on the administration of MSC secreted exosomes, many of the safety concerns and limitations associated with the transplantation of viable replicating cells could be mitigated.

In addition, exosomes have the capacity to carry a large cargo load, to protect the contents from degradative enzymes or chemicals and, because of low immunogenicity and stability, they represent optimal carriers for nanodelivery treatments. For instance, since the clinical application of PL is limited because of its short half-life and the variability of GF profiles among different donors (Marx, 2004; Pietramaggiori et al., 2008; Sugimori et al., 2006), the establishment of a PL-derived exosome factory may be envisaged for the delivery of adequate amounts of desired biological factors for effective bone regeneration strategies.

However, a complete knowledge of exosome content is an essential requirement before any exosome application. As mentioned above, exosomes contain proteins and RNA but they have also been implicated as a vehicle for viral and bacterial infection (Silverman and Reiner, 2011), including the assembly and release of HIV (Gould et al., 2003; Nguyen et al., 2003; von Schwedler et al., 2003) and intercellular spreading of infectious prions (Ritchie et al., 2013; Schneider and Simons, 2013). In addition, recently, it was reported that tumour cells (Balaj et al., 2011) and cardiomyocytes (Waldenström et al., 2012) release exosomes carrying DNA. Although the role of exosomal DNA is still unknown, it has been suggested that it could reach the cytosol of the target cells and be imported into the nucleus, where it may integrate into the genome, potentially leading to mutations, deletions, rearrangements and changes in gene expression. This aspect should be explicitly considered every time that cell culture supernatants or biological fluids, such as platelet derivatives, are applied both in vitro and in vivo studies. For instance, the analysis of exosomal content is a basic prerequisite, when pooled human platelet lysate (pPL) is used as medium supplement for ex vivo large-scale MSC isolation and expansion. In this situation, indeed, pPLexosomes deriving from different patients may possess diverse exosomal content and transport molecules, which may positively affect cell behaviour or compromise cell physiological functions.

In conclusion, our discovery of exosomes as additional effectors of PL activity provides valuable data that could result into a more focused application of platelet concentrates into the clinical setting.

Moreover, this study gives new insights into the biology of exosomes, highlighting some of their positive and negative features that need to be considered to develop new therapeutic nanodelivery systems.

\section{Conclusions}

In the present study we demonstrate, for the first time, that exosomes can be successfully isolated and purified from human PL. PL-derived exosomes increase MSC proliferation and migration at a higher extent than PL. In addition, exosome concentration affects the osteogenic differentiation of MSC. Preliminary analysis of exosome content revealed that PL-derived exosomes express bFGF, VEGF, PDGF-BB and TGF- $\beta 1$ and are enriched in short 
RNA. Our results provide significant evidence of exosomes as new additional effectors of PL, clarifying its activity on bone regeneration. In addition, our study highlights the importance of exosomes as a potential nanodelivery system for cell-free regeneration therapies.

\section{Acknowledgments}

This study was supported by a grant from the Italian Ministry of Health, '5 per mille' 2009.

\section{References}

Baglio SR, Pegtel DM, Baldini N (2012) Mesenchymal stem cells secreted vesicles provide novel opportunities in (stem) cell-free therapy. Front Physiol 3: 359.

Balaj L, Lessard R, Dai L, Cho YJ, Pomeroy SL, Breakefield XO, Skog J (2011) Tumor microvescicles contain retrotrasposon elements and amplified oncogene sequences. Nat Commun 2: 180.

Banward JC, Asher MA, Hassanein RS (1995) Iliac crest bone graft harvest donor site morbidity. Spine 20: 1055-1060.

Bard MP, Hegmans JP, Hemmes A, Luider TM, Willemsen R, Severijnen LA, van Meerbeeck JP, Burgers SA, Hoogsteden HC, Lambrecht BN (2004) Proteomic analysis of exosomes isolated from human malignant pleural effusions. Am J Respir Cell Mol Biol 31: 114-121.

Bieback K, Hecker A, Kocaömer A, Lannert H, Schallmoser K, Strunk D, Klüter H (2009) Human alternatives to fetal bovine serum for the expansion of mesenchymal stromal cells from bone marrow. Stem Cells 27: 2331-2341.

Brill A, Dashevsky O, Rivo J, Gozal Y, Varon D (20059 Platelet-derived microparticles induce angiogenesis and stimulate post-ischemic revascularization. Cardiovasc Res 67: 30-38.

Brill A, Elinav H, Varon D (2004) Differential role of platelet granular mediators in angiogenesis. Cardiovasc Res 63: 226-235.

$\mathrm{Bu}$ N, Li QL, Feng Q, Sun BZ (2006) Immune protection effect of exosomes against attack of L1210 tumor cells. Leuk Limphoma 47: 913-918.

Caby MP, Lankar D, Vincendeau-Scherrer C, Raposo G, Bonnerot C (2005) Exosomal-like vesicles are present in human blood plasma. Int Immunol 17: 879-887.

Camacho L, Guerrero P, Marchetti D (2013) MicroRNA and Protein Profiling of Brain Metastasis Competent CellDerived Exosomes. PLoS One 8: e73790.

Caplan AI and Correa D (2011) PDGF in bone formation and regeneration: new insights into a novel mechanism involving MSCs. J Orthop Res 29: 1795-1803.

Carter MJ, Fylling CP, Parnell LK (2011) Use of platelet rich plasma gel on wound healing: a systematic review and meta-analysis. Eplasty 11: 382-410.

Chen B, Sun HH, Wang HG, Kong H, Chen FM, Tu Q (2012) The effects of human platelet lysate on dental pulp stem cells derived from impacted human third molars. Biomaterials 33: 5023-5035.
Cho JW, Kim SA, Lee KS (2012) Platelet-rich plasma induces increased expression of G1 cell cycle regulators, type I collagen, and matrix metalloproteinase-1 in human skin fibroblasts. Int J Mol Med 29: 32-36.

Clayton A, Mitchell JP, Court J, Linnane S, Mason MD, Tabi Z (2008) Human tumor-derived exosomes downmodulate NKG2D expression. J Immunol 180: 7249-7258.

Clayton A, Mitchell JP, Court J, Mason MD, Tabi Z (2007) Human tumor-derived exosomes selectively impair lymphocyte responses to interleukin-2. Cancer Res 67: 7458-7466.

Dallari D, Savarino L, Stagni C, Cenni E, Cenacchi A, Fornasari PM, Albissini U, Rimondi E, Baldini N, Giunti A (2007) Enhanced tibial osteotomy healing with use of bone grafts supplemented with platelet gel or platelet gel and bone marrow stromal cells. J Bone Joint Surg Am 89: 2413-2420.

De Jong OG, Verhaar MC, Chen Y, Vader P, Gremmels H, Posthuma G, Schiffelers RM, Gucek M, van Balkom BWM (2012) Cellular stress conditions are reflected in the protein and RNA content of endothelial cell-derived exosomes. J Extracell Vescicles 1: 10.3402/jev.v1i0.18396.

Eckardt H, Ding M, Lind M, Hansen ES, Christensen KS, Hvid I (2005) Recombinant human vascular endothelial growth factor enhances bone healing in an experimental nonunion model. J Bone Joint Surg Br 87: 1434-1438.

Fekete N, Gadelorge M, Fürst D, Maurer C, Dausend J, Fleury-Cappellesso S, Mailänder V, Lotfi R, Ignatius A, Sensebé L, Bourin P, Schrezenmeier H, Rojewski MT (2012) Platelet lysate from whole blood-derived pooled platelet concentrates and apheresis-derived platelet concentrates for the isolation and expansion of human bone marrow mesenchymal stromal cells: production process, content and identification of active components. Cytotherapy 14: 540-554.

Fennis JP, Stoelinga PJ, Jansen JA (2002) Mandibular reconstruction: a clinical and radiographic animal study on the use of autogenous scaffolds and platelet-rich plasma. Int J Oral Maxillofac Surg 31: 281-286.

Fleming JE, Cornell CN, Muschler GF (2000) Bone cells and matrices in orthopaedic tissue engineering. Orthop Clin North Am 31: 357-374.

Foster TE, Puskas BL, Mandelbaum BR, Gerhardt MB, Rodeo SA (2009) Platelet-rich plasma: from basic science to clinical applications. Am J Sports Med 37: 2259-2272.

Franchini M, Dupplicato P, Ferro I, De Gironcoli M, Aldegheri R (2005) Efficacy of platelet

gel in reconstructive bone surgery. Orthopedics 28: 161163.

Froum SJ, Wallace SS, Tarnow DP, Cho SC (2002) Effect of platelet-rich plasma on bone growth and osseointegration in human maxillary sinus grafts: three bilateral case reports. Int J Periodontics Restorative Dent 22: 45-53.

Gandhi A, Bibbo C, Pinzur M, Lin SS (2005) The role of platelet-rich plasma in foot and ankle surgery. Foot Ankle Clin 10: 621-637.

Gerber HP, Vu TH, Ryan AM, Kowalski J, Werb Z, Ferrara N (1999) VEGF couples hypertrophic cartilage 
remodeling, ossification and angiogenesis during endochondral bone formation. Nat Med 5: 623-628.

Gonzales PA, Zhou H, Pisitkun T, Wang NS; Star RA, Knepper MA, Yuen PS (2010) Isolation and purification of exosomes in urine. Methods Mol Biol 641: 89-99.

Gould SJ, Booth AM, Hildretch JEK (2003) The Trojan exosome hyphotesis. Proc Natl Acad Sci USA 100: $10592-$ 10597.

Govidasami V, Ronald VS, Abdullah AN, Ganesan Nathan KR, Aziz ZA, Abdullah M, Zain RB, Kasim NH, Musa S, Bhonde RR (2011) Human platelet lysate permits scale-up of dental pulp stromal cells for clinical applications. Cytotherapy 13: 1221-1233.

Graham S, Leonidou A, Lester M, Heliotis M, Mantalaris A, Tsiridis E (2009) Investigating the role of PDGF as a potential drug therapy in bone formation and fracture healing. Expert Opin Investig Drugs 18: 16331654.

Granchi D, Devescovi V, Pratelli L, Verri E, Magnani M, Donzelli O, Baldini N (2013) Serum levels of fibroblast growth factor 2 in children with orthopaedic diseases: potential role in predicting bone healing. J Orthop Res 31: 249-256.

Grant R, Ansa-Addo E, Stratton D, Antwi-Baffour S, Jorfi S, Kholia S, Krige L, Lange S, Inal J (2011) J Immunol Methods 371: 143-151.

Hall MP, Ward JP, Cardone DA (2013) Platelet rich placebo? Evidence for platelet rich plasma in the treatment of tendinopathy and augmentation of tendon repair. Bull Hosp Jt Dis 71: 54-59.

Hee HT, Majd ME, Holt RT, Myers L (2003) Do autologous growth factors enhance transforaminal lumbar interbody fusion? Eur Spine J 12: 400-407.

Heijnen HF, Schiel AE, Fijnheer R, Geuze HJ, Sixma JJ (1999) Activated platelets release two types of membrane vescicles: microvescicles by surface shedding and exosomes derived from exocytosis of multivescicular bodies and alpha-granules. Blood 17: 578-584.

Hemeda H, Giebel B, Wagner W (2014) Evaluation of human platelet lysate versus fetal bovine serum for culture of mesenchymal stromal cells. Cytotherapy 16: 170-80.

Italiano JR Jr, Mairuhu AT, Flaumenhaft R (2010) Clinical relevance of microparticles from platelets and megakaryocytes. Curr Opin Hematol 94: 3791-3799.

Jonsdottir-Buch SM, Lieder R, Sigurjonsson OE (2013) Platelet lysates produced from expired platelet concentrates support growth and osteogenic differentiation of mesenchymal stem cells. PloS One 8: e68984.

Kawaguchi H, Oka H, Jingushi S, Izumi T, Fukunaga M, Sato K, Matsushita T, Nakamura K; TESK Group (2010) A local application of recombinant human fibroblast growth factor 2 for tibial shaft fractures: a randomized, placebo-controlled trial. J Bone Miner Res 25: 2735-2743.

Keller S, Ridinger J, Rupp AK, Janssen JW, Altevogt P (2011) Body fluid derived exosomes as a novel template for clinical diagnostics. J Transl Med 9: 86.

Kempen DH, Creemers LB, Alblas J, Lu L, Verbout AJ, Yaszemski MJ, Dhert WJ (2010) Growth factor interactions in bone regeneration. Tissue Eng Part B Rev 16: 551-566.
Kharaziha P, Ceder S, Li Q, Panaretakis T (2012) Tumor cell-derived exosomes: a message in a bottle. Biochim Biophys Acta 1826: 103-111.

Kilian O, Flesch I, Wenisch S, Taborski B, Jork A, Schnettler R, Jonuleit T (2004) Effects of platelet growth factors on human mesenchymal stem cells and human endothelial cells in vitro. Eur J Med Res 9: 337-344.

Lai RC, Arslan F, Lee MM, Sze NS, Choo A, Chen TS, Salto-Tellez M, Timmers L, Lee CN, El Oakley RM, Pasterkamp G, de Kleijn DP, Lim SK (2010) Exosome secreted by MSC reduces myocardial ischemia/reperfusion injury. Stem Cell Res 4: 214-222.

Lai RC, Chen TS, Lim SK (2011) Mesenchymal stem cell exosome: a novel stem cell-based therapy for cardiovascular disease. Regen Med 6: 481-492.

Lane JG, Healey RM, Chase DC, Amiel D (2013) Use of platelet-rich plasma to enhance tendon function and cellularity. Am J Orthop 42: 209-214.

Lasser JG, Alikhani VS, Ekstrom K, Eldh M, Paredes PT, Bossios A, Sjöstrand M, Gabrielsson S, Lötvall J, Valadi H (2011) Human saliva, plasma and breast milk exosomes contain RNA: uptake by macrophages. J Transl Med 9: 9 .

Lee JC, Min HJ, Park HJ, Lee S, Seong SC, Lee MC (2013) Synovial membrane-derived mesenchymal stem cells supported by platelet-rich plasma can repair osteochondral defects in a rabbit model. Arthroscopy 29: 1034-1046.

Lee KS (2013) Platelet-rich plasma injection. Semin Musculoskelet Radiol 17: 91-98.

Lehmann BD, Paine MS, Brooks AM, McCubrey JA, Renegar RH, Wang R, Terrian DM (2008) Senescenceassociated exosome release from human prostate cancer cells. Cancer Res 68: 7864-7871.

Liao HT, Marra K, Rubin PJ (2014) Application of platelet-rich plasma and platelet-rich fibrin in fat graftin: basic science and literature review. Tissue Eng Part B Rev 20: $267-276$.

Lieberman JR, Daluiski A, Einhorn TA (2002) The role of growth factors in the repair of bone. Biology and clinical applications. J Bone Joint Surg Am 84-A: 1032-1044.

Lind, M (1998) Growth factor stimulation of bone healing. Effects on osteoblasts, osteomies, and implants fixation. Acta Orthop Scand Suppl 283: 2-37.

Lohmann M, Walenda G, Hemeda H, Joussen S, Drescher W, Jockenhoevel S, Hutschenreuter S, Zenke M, Wagner W (2012) Donor age of human platelet lysate affects proliferation and differentiation of mesenchymal stem cells. PloS One 7: e37839.

Lv LL, Cao YH, Ni HF, Xu M, Liu D, Liu H, Chen PS, Liu BC (2013) MicroRNA-29c in urinary exosome/ microvesicle as a biomarker of renal fibrosis. Am J Physiol Renal Physiol 305: F1220-1227.

Malhotra A, Pelletier MH, Yu Y, Walsh WR (2013) can platelet-rich plasma (PRP) improve bone haeling? A comparison between the theory and experimental outcomes. Arch Orthop Trauma Surg 133: 153-165.

Malik A, Shaari R, Rahman SA, Aljuboori MJ (2012) Influence of platelet-rich plasma on dental implants. 
Osseointegration in well-controlled diabetic patients. Dent Implantol Update 23: 89-96.

Marx RE (2004) Platelet-rich plasma: evidence to support its use. J Oral Maxillofac Surg 62: 489.

Mathivanan S, Ji H, Simpson RJ (2010) Exosomes: extracellular organelles important in intercellular communication. J Proteomics 73: 1907-1920.

Mineo M, Garfield SH, Taverna S, Flugy A, De Leo G, Alessandro R, Kohn EC (2012) Exosomes released by K562 chronic myeloid leukemia cells promote angiogenesis in a src-dependent fashion. Angiogenesis 15: $33-45$.

Moldovan L, Batte K, Wang Y, Wisler J, Piper M (2013) Analyzing the circulating microRNAs in exosomes/ extracellular vesicles from serum or plasma by qRT-PCR. Methods Mol Biol 1024: 129-145.

Montero A, Okada Y, Tomita M, Ito M, Tsurukami H, Nakamura T, Doetschman T, Coffin JD, Hurley MM (2000) Disruption of the fibroblast growth factor- 2 gene results in decreased bone mass and bone formation. J Clin Invest 105: 1085-1093.

Moore DC, Ehrlich MG, McAllister SC, Machan JT, Hart CE, Voigt C, Lesieur-Brooks AM, Weber EW (2009) Recombinant human platelet-derived growth factor-BB augmentation of new-bone formation in a rat model of distraction osteogenesis. J Bone Joint Surg Am 91: 1973 1984.

Nguyen DG, Booth A, Gould SJ, Hildreth JE (2003) Evidence that HIV budding in primary macrophages occurs through the exosome release pathway. J Biol Chem 278: 52347-52354.

Nguyen RT, Borg-Stein J, McInnis K (2011) Applications of platelet-rich plasma in musculoskeletal and sports medicine: an evidence-based approach. PM R 3: 226-250.

O’Brien K, Rani S, Corcoran C, Wallace R, Hughes L, Friel AM, MsDonnell S, Crown J, Radomski MW, O’Driscoll L (2013) Exosomes from triple-negative breast cancer cells can transfer phenotypic traits representing their cells of origin to secondary cells. Eur J Cancer 49: 1845-1859.

Passaretti F, Tia M, D'Esposito V, Pascale MD, Corso MD, Sepulveres R, Liguoro D, Valentino R, Beguinot F, Formisano P, Sammartino G (2014) Growth-promoting action and growth factor release by different platelet derivates. Platelets 25: 252-256

Perut F, Filardo G, Mariani E, Cenacchi A, Pratelli L, Devescovi V, Kon E, Marcacci M, Facchini A, Baldini N, Granchi D (2013) Preparation methods and growth factor content of platelet concentrate influence the osteogenic differentiation of bone marrow stromal cells. Cytotherapy 15: 830-839.

Pietramaggiori G, Scherer SS, Mathews JC, Alperovich M, Yang HJ, Neuwalder J, Czeczuga JM, Chan RK, Wagner CT, Orgill DP (2008) Healing modulation induced by freeze-dried platelet-rich plasma and micronized allogenic dermis in a diabetic wound model. Wound Repair Regen 16: $218-225$

Plé H, Landry P, Benham A, Coarfa C, Gunaratne PH, Provost P (2012) The repertoire and features of human platelet microRNAs. PloS One 12:e50746. doi: 10.1371/ journal.pone.0050746.

Presta M, Dell'Era P, Mitola S, Moroni E, Ronca R, Rusnati M (2006) Fibroblast growth factor/fibroblast growth factor receptor system in angiogenesis. Cytokine Growth Factor Rev 16: 159-178.

Raposo G, Nijman HW, Stoorvogel W, Liejendekker R, Harding CV, Melief CJ, Geuze HJ (1996) B lymphocytes secrete antigen-presenting vesicles. J Exp Med 183: 11611172.

Record M, Subra C, Silvente-Poirot S, Poirot M (2011) Exosomes as intercellular signalosomes and pharmacological effectors. Biochem Pharmacol 81: 11711182.

Rendu F, Brohard-Bohn B (2001) The platelet release reaction: granules constituents, secretion and functions. Platelets 12: 261-273.

Rhee JS, Black M, Schubert U, Fischer S, Morgenstern E, Hammes HP, Preissner KT (2004) The functional role of blood platelet components in angiogenesis. Thromb Haemost 92: 394-402.

Ritchie AJ, Crawford DM, Ferguson DJ, Burthem J, Roberts DJ (2013) Normal prion protein is expressed on exosomes isolated from human plasma. Br J Haematol 163: 678-80.

Roccaro AM, Sacco A, Maiso P, Azab AK, Tai YT, Reagan M, Azab F, Flores LM, Campigotto F, Weller E, Anderson KC, Scadden DT, Ghobrial IM (2013) BM mesenchymal stromal cell-derived exosomes facilitate multiple myeloma progression. J Clin Invest 123: 15421555.

Ruggiu A, Ulivi V, Sanguineti F, Cancedda R, Descalzi F (2013) The effect of Platelet Lysate on osteoblast proliferation with a transient increase of the inflammatory response in bone regeneration. Biomaterials 34: 93189330.

Sahoo S, Klychko E, Thorne T, Misener S, Schultz KM, Millay M, Ito A, Liu T, Kamide C, Agrawal H, Perlman H, Qin G, Kishore R, Losordo DW (2011) Exosomes from human $\mathrm{CD} 34(+)$ stem cells mediate their proangiogenic paracrine activity. Circ Res 109: 724-728.

Salomon C, Ryan J, Sobrevia L, Kobayashi M, Ashman K, Mitchell M, Rice GE (2013) Exosomal signaling during hypoxia mediates microvascular endothelial cell migration and vasculogenesis. PloS One 8: e68451.

Sanchez M, Azofra J, Anitua E, Andia I, Padilla S, Santisteban J, Mujika I (2003) Plasma rich in growth factors to treat an articular cartilage avulsion: a case report. Med Sci Sports Exerc 35: 1648-1652.

Sanderson MP, Keller S, Alonso A, Riedle S, Dempsey PJ, Altevogt P (2008) Generation of novel, secreted epidermal growth factor receptor (EGFR/ErbB1) isoforms via metalloprotease dependent ectodomain shedding and exosome secretion. J Cell Biochem 103:1783-1797.

Savarino L, Cenni E, Tarabusi C, Dallari D, Stagni C, Cenacchi A, Fornasari PM, Giunti A, Baldini N (2006) Evaluation of bone healing enhancement by lyophilized bone grafts supplemented with platelet gel: a standardized methodology in patients with tibial osteotomy for genu varus. J Biomed Mater Res B Appl Biomater 76: 364-372. 
Schallmoser K, Bartmann C, Rohde E, Reinisch A, Kashofer K, Stadelmeyer E, Drexler C, Lanzer G, Linkesch W, Strunk D (2007) Human platelet lysate can replace fetal bovine serum for clinical-scale expansion of functional mesenchymal stromal cells. Transfusion 47: 1436-1446.

Schallmoser K, Rohde E Reinisch A Bartmann C, Thaler D, Drexler C, Obenauf AC, Lanzer G, Linkesch W, Strunk D (2008) Rapid large-scale expansion of functional mesenchymal stem cells from unmanipulated bone marrow without animal serum. Tissue Eng Part C Methods 14: 185-196.

Schliephake H (2002) Bone growth factors in maxillofacial skeletal reconstruction. Int J Oral Maxillofac Surg 31: 469-484.

Schmidt A, Ladage D, Schinkothe T, Klausmann U, Ulrichs C, Klinz FJ, Brixius K, Arnhold S, Desal B, Mehlhorn U, Schwinger RHG, Staib P, Addicks K, Bloch W (2006) Basic fibroblast growth factor controls migration in human mesenchymal stem cells. Stem Cells 24:17501758 .

Schneider A, Simons M (2013) Exosomes: vescicular carriers for intercellular communication in neurodegenerative disorders. Cell Tissue Res 352: 33-47.

Seelenmeyer C, Stegmayer C, Nickel W (2008) Unconventional secretion of fibroblast growth factor 2 and galectin-1 does not require shedding of plasma membranederived vesicles. FEBS Lett 582: 1362-1368.

Silverman JM, Reiner NE (2011) Exosomes and other microvescicles in infection biology: organelles with unanticipated phenotypes. Cell Microbiol 13: 1-9.

Slater M, Patava J, Kingham K, Mason RS (1995) Involvement of platelets in stimulating osteogenic activity. J Orthop Res 13: 655-663.

Soffer E, Ouhayoun JP, Anagnostou F (2003) Fibrin sealants and platelet preparations in bone and periodontal healing. Oral Surg Oral Med Oral Pathol Oral Radiol Endod 95: 521-528.

Sokolova V, Ludwig AK, Hornung S, Rotan O, Horn PA, Epple M, Giebel B (2011) Characterisation of exosomes derived from human cells by nanoparticle tracking analysis and scanning electron microscopy. Colloids Surf B Biointerfaces 87: 146-150.

Sugimori E, Shintani S, Ishikawa K, Hamakawa H (2006) Effects of apatite foam combined with platelet-rich plasma on regeneration of bone defects. Dent Mater J 25: 591-596.

Théry C, Amigorena S, Raposo G, Clayton A (2006) Isolation and characterization of exosomes from cell culture supernatants and biological fluids. Curr Protoc Cell Biol 3: Unit 3.22.

Théry C, Regnault A, Garin J, Wolfers J, Zitvogel L, Ricciardi-Castagnoli P, Raposo G, Amigorena S (1999) Molecular characterization of dendritic cell-derived exosomes. Selective accumulation of the heat shock protein hsc73. and function. J Cell Biol 147: 599-610.

Théry C, Zitvogel L, Amigorena S (2002) Exosomes: composition, biogenesis and function. Nat Rev Immunol 2: 569-579.

Tomasoni S, Longaretti L, Rota C, Morigi M, Conti S, Gotti E, Capelli C, Introna M, Remuzzi G, Benigni A (2013) Transfer of growth factor receptor mRNA via exosomes unravels the regenerative effect of mesenchymal stem cells. Stem Cell Dev 22: 772-778.

Trompeter HI, Dreesen J, Hermann E, Iwaniuk KM, Hafner M, Renwick N, Tuschl T, Wernet P (2013) MicroRNAs miR-26a, miR-26b, and miR-29b accelerate osteogenic differentiation of unrestricted somatic stem cells from human cord blood. BMC Genomics 14: 111.

Urbanelli L, Magini A, Buratta S, Brozzi A, Sagini K, Polchi A, Tancini B, Emiliani C (2013) Signaling pathways in exosomes biogenesis, secretion and fate. Genes 4: 152170.

Valadi H, Ekstrom K, Bossios A, Sjostrand M, Lee JJ, Lotvall JO (2007) Exosome-mediated transfer of mRNAs and microRNAs is a novel mechanism of genetic exchange between cells. Nat Cell Biol 9: 654-659.

Van Bergen CJ, Kerkhoffs GM, Ozdemir M, Korstjens CM, Everts V, van Ruijven LJ, van Dijk CN, Blankevoort L (2013) Demineralized bone matrix and platelet-rich plasma do not improve healing of osteochondral defects of the talus: an experimental goat study. Osteoarthritis Cartilage 21: $1746-1754$.

Von Schwedler UK, Stuchell M, Muller B, Ward DM, Chung HY, Morita E, Wang HE Davis T, He GP, Cimbora DM, Scott A, Kräusslich HG, Kaplan J, Morham SG, Sundquist WI (2003) The protein network of HIV budding. Cell 144: 701-713.

Waldenström A, Gennebäck N, Hellman U, Ronquist G (2012) Cardiomyocyte microvescicles contain DNA/RNA and convey biological messages to target cells. PLoS One 7: e34653.

Wang GJ, liu Y, Qin A, Shah SV, Deng ZB, Xiang X, Cheng Z, Liu C, Wang J, Zhang J, Zhang L, Grizzle WE, Zhang HG (2008) Thymus exosomes-like particles induce regulatory T cells. J Immunol 181: 5242-5248.

Warnke PH, Humpe A, Strunk D, Stephens S, Warnke F, Wiltfang J, Schallmoser K, Alamein M, Bourke R, Heiner P, Liu Q (2013) A clinically-feasible protocol for using human platelet lysate and mesenchymal stem cells in regenerative therapies. J Craniomaxillofac Surg 41: 153-161.

Yang X, Meng S, Jiang H, Zhu C, Wu W (2011) Exosomes derived from immature bone marrow dendritic cells induce tolerogenicity of intestinal transplantation in rats. J Surg Res 171: 826-832.

Zhang BG, Li JF, Yu BQ, Zhu ZG, Liu BY, Yan M (2012) microRNA-21 promotes tumor proliferation and invasion in gastric cancer by targeting PTEN. Oncol Rep 27: 1019-1026.

Zhang HC, Liu XB, Huang S, Bi XY, Wang HX, Xie LX, Wang YQ, Cao XF, Lv J, Xiao FJ, Yang Y, Guo ZK (2012) Microvesicles derived from human umbilical cord mesenchymal stem cells stimulated by hypoxia promote angiogenesis both in vitro and in vivo. Stem Cells Dev 21: 3289-3297.

Zhang HG, Liu C, Su K, Yu S, Zhang L, Zhang S, Wang J, Cao X, Grizzle W, Kimberly RP (2006) A membrane form of TNF- $\{$ alpha $\}$ presented by exosomes delays T cell activation induced cell death. J Immunol 176: 7385-7893.

Zhao B, Han H, Chen J, Zhang Z, Li S, Fang F, Zheng Q, Ma Y, Zhang J, Wu N, Yang Y (2014) MicroRNA let-7c inhibits migration and invasion of human non-small cell 
lung cancer by targeting ITGB3 and MAP4K3. Cancer Lett 342: 43-51.

Zhu Y, Yuan M, Meng HY, Wang AY, Guo QY, Wang Y, Peng Y (2013) Basic science and clinical application of platelet-rich plasma for cartilage defects and osteoarthritis: a review. Osteoarthritis Cartilage 21: 1627-1637.

\section{Discussion with Reviewers}

M. Alini: The concentration of exosomes in PL is 10-times less than that used to evaluate MSC proliferation. To prove exosomes activity (In PL) towards MSC proliferation, the authors should use the concentration measured in PL. Please comment.

Authors: According to the editor's suggestions, we performed the proliferation assay by using the concentration of exosomes contained into $10 \% \mathrm{PL}(0.6 \mu \mathrm{g})$.

The effect of exosomes is dose dependent. The amount of $0.6 \mu \mathrm{g}$ is sufficient to induce a significant increase of MSC proliferation (see Fig. 3). However, the proliferation rate observed with $0.6 \mu \mathrm{g}$ is significantly lower than that observed with $10 \% \mathrm{PL}$, since the effect of PL is mediated also by free growth factors contained into PL preparation. This hypothesis is supported also by Hemeda et al. (Hemeda et al., 2014, text reference) who recently reported the importance of several factors (i.e., growth factors, metabolites, etc.) to be considered in PL activity.

M. Herrmann: The findings in your study are new - are they clinically applicable? Is there a possibility to modify exosomes to ultimately boost their effect?

Authors: Up to now there are only few studies in literature where exosomes have been used in clinical trials (Dai, 2008; Escudier et al., 2005; Morse et al., 2005, additional references). Exosomes represent a challenging opportunity for new effective therapeutic applications. Indeed, they may be modified to become well-suited biologically active vectors able to deliver a broad variety of cargos (Sun et al., 2010; Alvarez-Erviti et al, 2011: Lai et al., 2013; Tian et al., 2014, additional references). However, for translation of exosomes to the clinic, exosome isolation and characterisation methods should be standardised and large-scale production must be developed.

S. Lippross: Uptake experiments are preliminary and solely based on microscopy. A proof of internalisation of exosomes is missing. Please comment.

Authors: As demonstrated by other papers (Mineo et al., 2012, text reference; Camacho et al., 2013; Roccaro et al., 2013; Riches et al., 2014, additional references), analysis performed by microscopy represents one of the main methods used to assess exosome uptake.

S. Lippross: The quantification results of the Alizarin Red staining do not correspond to the pictures shown in Fig. 5a. Please comment.
Authors: The quantification of Alizarin Red staining is a mean derived from three independent experiments, while images are only representative. The trend is virtually the same; moreover, the quantification assay is more sensitive, thus able to reveal different levels of mineralisation not appreciable using optical microscopy.

\section{Additional References}

Alvarez-Erviti L, Seow Y, Yin H, Betts C, Lakhal S, Wood MJ (2011) Delivery of siRNA to the mouse brain by systemic injection of targeted exosomes. Nat Biotechnol 29: 341-345.

Camacho L, Guerrero P, Marchetti D (2013) MicroRNA and protein profiling of brain metastasis competent cellderived exosomes. PLoS One 8: e73790.

Dai S, Wei D, Wu Z, Zhou X, Wei X, Huang H, Li G (2008) Phase I clinical trial of autologous ascites-derived exosomes combined with gm-csf for colorectal cancer. Mol Ther 16: 782-790.

Escudier B, Dorval T, Chaput N, André F, Caby MP, Novault S, Flament C, Leboulaire C, Borg C, Amigorena $\mathrm{S}$, Boccaccio C, Bonnerot C, Dhellin O, Movassagh M, Piperno S, Robert C, Serra V, Valente N, Le Pecq JB, Spatz A, Lantz O, Tursz T, Angevin E, Zitvogel L (2005) Vaccination of metastatic melanoma patients with autologous dendritic cell (DC) derived-exosomes: results of the first phase I clinical trial. J Transl Med 3: 10.

Lai RC, Yeo RW, Tan KH, Lim SK (2013) Exosomes for drug delivery - a novel application for the mesenchymal stem cell. Biotechnol Adv 31: 543-551.

Morse MA, Garst J, Osada T, Khan S, Hobeika A, Clay TM, Valente N, Shreeniwas R, Sutton MA, Delcayre A, Hsu DH, Le Pecq JB, Lyerly HK (2005) A phase I study of dexosome immunotherapy in patients with advanced non-small cell lung cancer. J Transl Med 3: 9.

Riches A, Campbell E, Borger E, Powis S (2014) Regulation of exosome release from mammary epithelial and breast cancer cells - a new regulatory pathway. Eur J Cancer 50: 1025-1034.

Roccaro AM, Sacco A, Maiso P, Azab AK, Tai YT, Reagan M, Azab F, Flores LM, Campigotto F, Weller E, Anderson KC, Scadden DT, Ghobrial IM (2013) BM mesenchymal stromal cell-derived exosomes facilitate multiple myeloma progression. J Clin Invest 123: 15421555.

Sun D, Zhuang X, Xiang X, Liu Y, Zhang S, Liu C, Barnes S, Grizzle W, Miller D, Zhang HG (2010) A novel nanoparticle drug delivery system: the anti-inflammatory activity of curcumin is enhanced when encapsulated in exosomes. Mol Ther 18: 1606-1614.

Tian Y, Li S, Song J, Ji T, Zhu M, Anderson GJ, Wei J, Nie G (2014) A doxorubicin delivery platform using engineered natural membrane vesicle exosomes for targeted tumor therapy. Biomaterials 35: 2383-2390. 